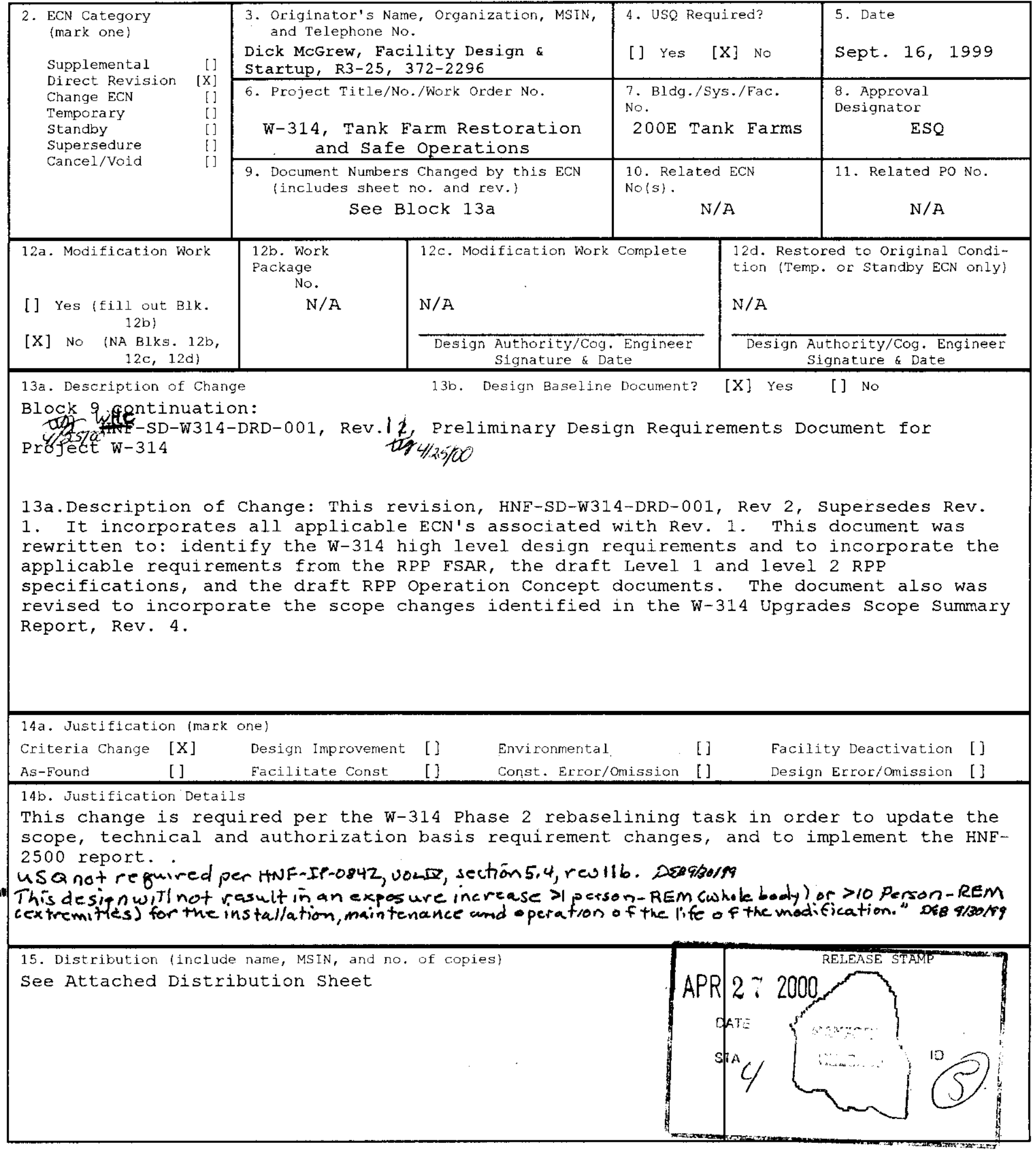




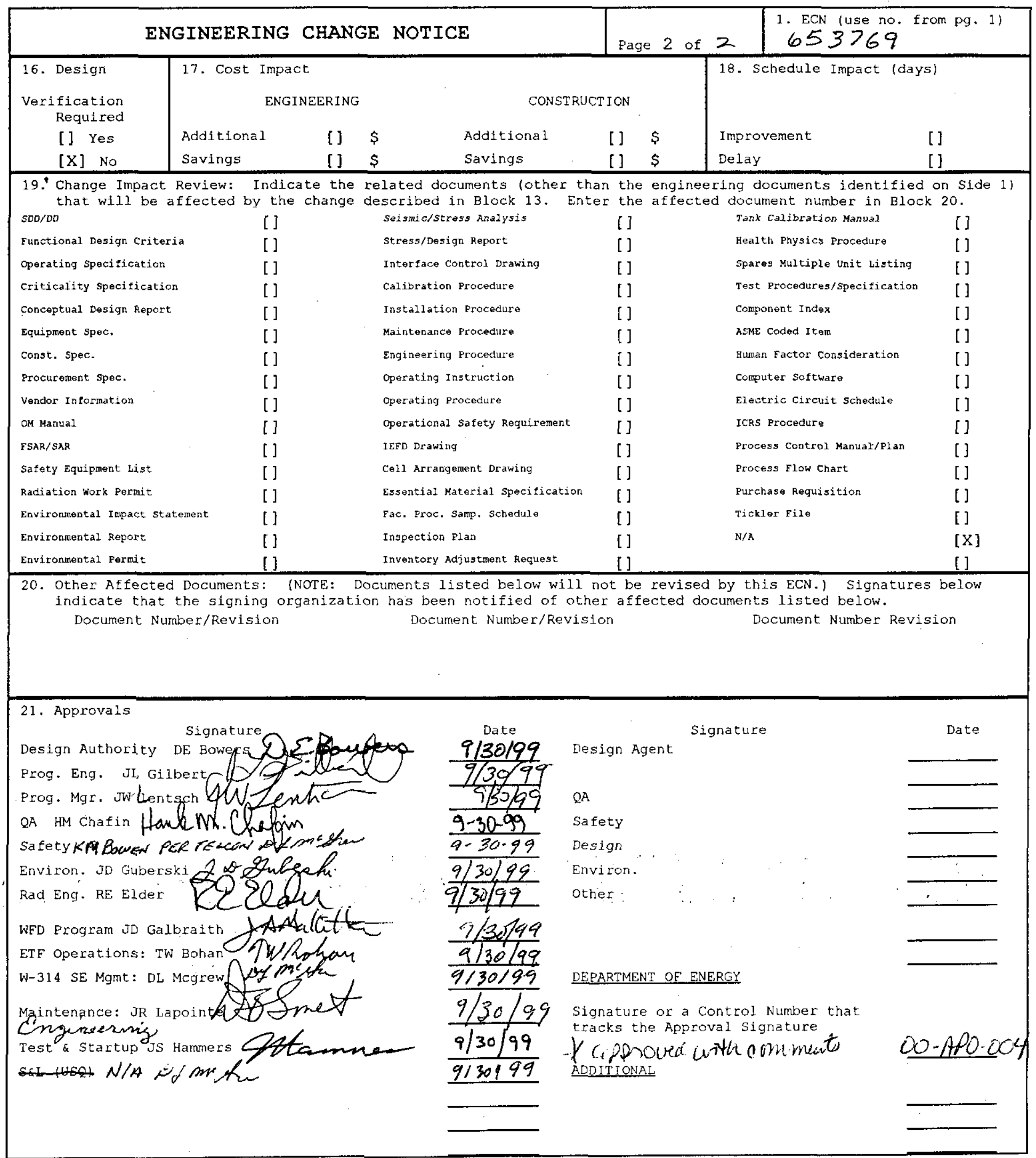




\title{
Preliminary Design Requirements Document for Project W-314
}

\author{
D. L. McGrew \\ Numatec Hanford Corporation \\ Richland, WA 99352 \\ U.S. Department of Energy Contract DE-AC06-96RL13200 \\ EDT/ECN: \\ UC: \\ Org Code: 7C300 \\ Charge Code: 109749 \\ B\&R Code: \\ Total Pages: 66
}

Key Words: Design Requirements Document, Project $W-314$, Tank Farm Restoration and Safe Operations

Abstract: This document sets forth functional requirements, performance requirements, and design constraints for the tank farm systems elements identified in section 3.1 of this document. These requirements shall be used to develop the Design Requirements Baseline for those system elements.

TRADEMARK DISCLAIMER. Reference herein to any specific commercial product, process, or service by trade name, trademark, manufacturer, or otherwise, does not necessarily constitute or imply its endorsement, recommendation, or favoring by the United States Government or any agency thereof or its contractors or subcontractors.

Printed in the United States of America. To obtain copies of this document, contact: Document Control Services, P.O. Box 950, Mailstop H6-08, Richland WA 99352, Phone (509) 372-2420; Fax (509) 376-4989.
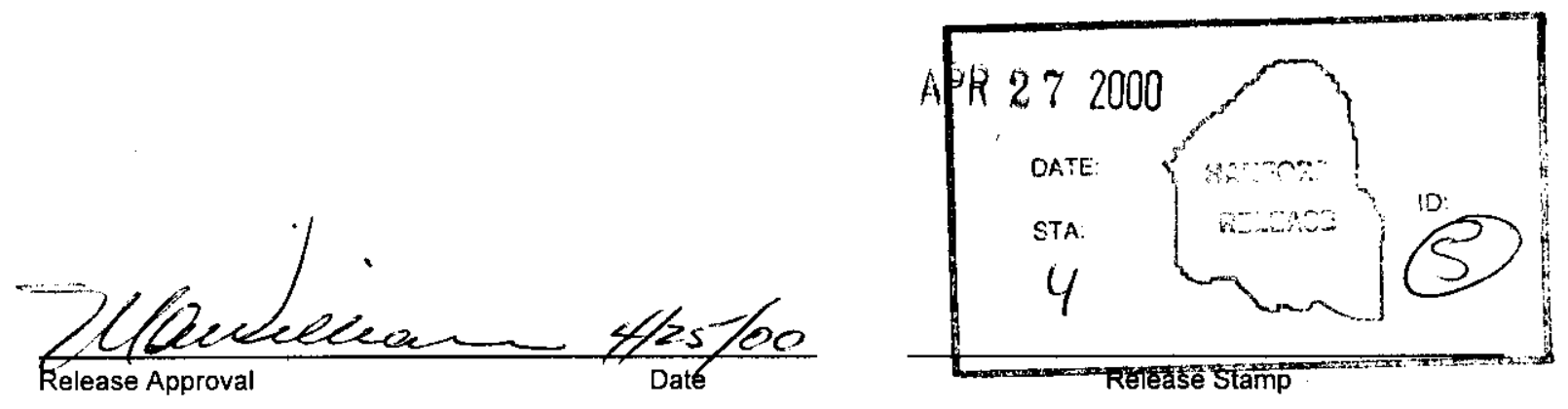

\section{Approved For Public Release}




\section{RECORD OF REVISION}

(1) Document Number

HNE-SD-W314-DRD-001

(2) Title

Preliminary Design Requirements Document for Project $W-314$

Change Control Record

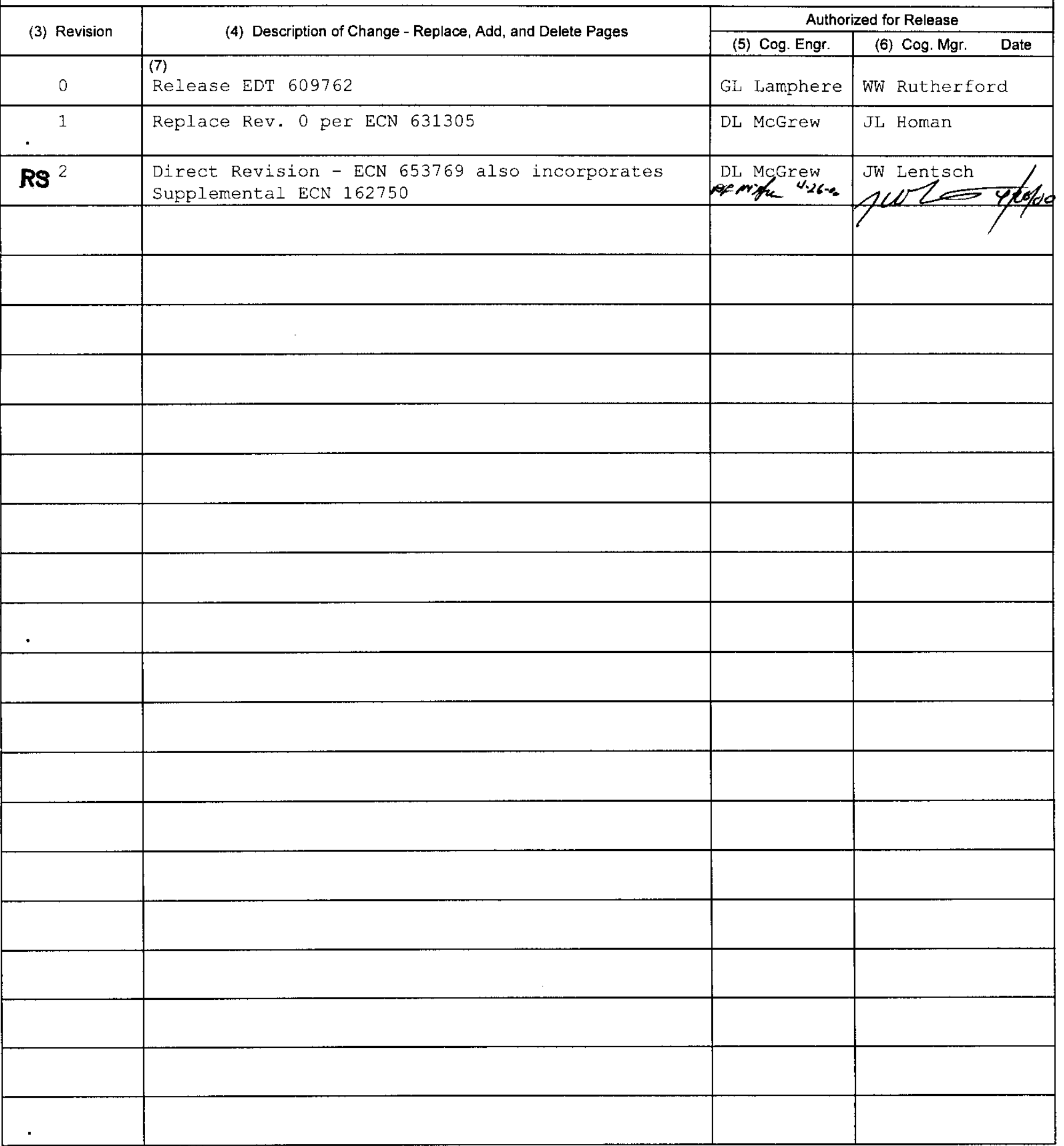


HNF-SD-W314-DRD-001, Rev. 2

\title{
Preliminary Design Requirements Document for
}

\author{
Project W-314 \\ Tank Farm Restorations and Safe Operations \\ Prepared for: \\ U.S. Department of Energy \\ Office of River Protection \\ P.O. Box 550 \\ Richland, Washington 99352 \\ Prepared by: \\ Lockheed Martin Hanford Corporation \\ P.O. Box 1500 \\ Richland, WA 99352
}

September 1999 


\section{Table of Contents}

1 SCOPE

1.1 Identification.

1.2 System Overview.

1.3 Document Overview.

2 APPLICABLE DOCUMENTS

2.1 COMPLIANCE DOCUMENTS

2.2 REFERENCE DOCUMENTS

3 REQUIREMENTS

3.1 Project Definition.

3.1.1 Systems Elements Purpose

3.1.1.1 W-314 System Elements.

3.1.1.2 Instrumentation and Displays.______ 3-3

3.1.1.3 Ventilation and Cooling System.__ 3-3

3.1.1.4 W-314 Transfer System Elements.__ 3-3

3.1.1.5 Electrical Distribution Elements.__ 3-3

3.1.2 Interface Definition.__ 3-3

3.1.2.1 Hanford Site Utilities.__ 3-3

3.1.2.2 Tank Farm System - 200 East.____ 3-3

3.1.2.3 Tank Farm System - 200 West.___ 3-4

3.1.2.4 Project W-211 Initial Tank Retrieval System.___ 3-5

3.1.2.5 Project W-519, Privatization Infrastructure Phase 1 Support System.___ 3-6

3.1.2.6 Project W-521, Waste Feed Delivery.__ 3-6

3.1.2.7 Project W-522, DST Retrieval.__ 3-7

3.1.2.8 Current Project List.___ 3-7

$\begin{array}{lll}3.2 & \text { Characteristics.___ 3-7 }\end{array}$

3.2.1 System Performance.__ 3-7

3.2.1.1 DST Waste Storage.__ 3-7

3.2.1.1.1 Control DST Temperature.___ 3-7

3.2.1.1.1.1 Maintain DST Waste Temperature within Limiting Conditions for Operation and Safety Limit.

3.2.1.1.1.1.1 Ventilating to Maintain Waste Temperatures below Limiting Conditions for Operation (LCO).

3.2.1.1.2 Control DST Vapor Space Pressure.___ 3-8

3.2.1.1.2.1 Maintain DST Vapor Space Pressure within Limits.___ 3-8

3.2.1.1.2.1.1 Ventilate to Maintain DST Vapor Space Pressure to within Limits.___ 3-8

3.2.1.1.3 Control DST Gaseous Discharge.__ 3-8

3.2.1.1.3.1 Monitor DST Gaseous Effluent Discharge.___ 3-8

3.2.1.1.3.1.1 Record Sampling Systems for Ventilation Exhaust Stacks.__ 3-8

3.2.1.1.3.1.2 Design Requirements for Sample System and Stack Flow Rate Instruments.___ 3-8

3.2.1.1.3.1.3 Operating the CAM during Exhaust System Operation.__ 3-8 
3.2.1.1.3.2 Maintain DST Gaseous Effluent Discharge within Authorized Limits.

3.2.1.1.3.2.1 Control of Toxic and Hazardous Substance.__ 3-9

3.2.1.1.3.2.2 HEPA Filter Particulate Removal Efficiency.___ 3-9

3.2.1.1.3.2.3 HEPA Filter Description._- 3-9

3.2.1.1.3.2.4 CAM Interlock Shutdown during Excessive Radiation Levels.__ 3-9

3.2.1.1.4 DST Flammable Gas Concentration.__ 3-9

3.2.1.1.4.1 Maintain DST Flammable Gas Concentrations within Lower Flammability Limits.

3.2.1.1.4.1.1 Provide Sufficient Primary Tank Vapor Space Flow to Maintain

Flammable Gas Concentration below Lower Flammability Limit.___ 3-9

3.2.1.2 DCRT Waste Storage._ 3-9

3.2.1.2.1 Control DCRT Temperature._________ 3-9

3.2.1.2.1.1 Maintain DCRT Waste Temperature within the Safety Limits.___ 3-9

3.2.1.2.1.1.1 Ventilate to Maintain DCRT Waste Temperature within Safety Limit.___ 3-9

3.2.1.2.2 Control DCRT Vapor Space Pressure.___ 3-10

3.2.1.2.2.1 Maintain DCRT Vapor Space Pressure Within Limits.___ 3-10

3.2.1.2.2.1.1 Maintain Ventilation Vacuum in DCRT.__ 3-10

3.2.1.2.3 Control DCRT Gaseous Effluent.___ 3-10

3.2.1.2.3.1 Monitor DCRT Gaseous Effluent Discharge.__ 3-10

3.2.1.2.3.1.1 Record Sampling Systems for Ventilation Exhaust Stacks.__ 3-10

3.2.1.2.3.1. Design Requirements for Sample System and Stack Flow Rate Instruments.

3.2.1.2.3.1.3 Operating the CAM during Exhaust System Operation.

3-10

3.1.12.3

3.2.1.2.3.2.1 Control of Toxic and Hazardous Substances._- 3-10

3.2.1.2.3.2.2 HEPA Filter Particulate Removal Efficiency.___ 3-10

3.2.1.2.3.2.3 HEPA Filter Description.__ 3-11

3.2.1.2.3.2.4 CAM Interlock Shutdown during Excessive Radiation Levels.___ 3-11

3.2.1.2.4 DCRT Flammable Gas Concentration._____ 3-11

3.2.1.2.4.1 Maintain DCRT Flammable Gas Concentration within Limiting Condition for Operation.

3.2.1.2.4.1.1 Provide Sufficient Tank Vapor Space Flow to Maintain Flammable Gas Concentration below Lower Flammability Limit.

3.2.1.3 Transfer Managed Tank Waste.

3.2.1.3.1 Confine Waste Along Transfer Route.

3.2.1.3.1.1 Confine Waste Within the Valve Manifolds and Jumpers.___ 3-11

3.2.1.3.1.1.1 Visible Leakage Test Boundaries.___ 3-11

3.2.1.3.2 Confine Waste Leakage Along Transfer Route.__ 3-11

3.2.1.3.2.1 Confine Waste Leakage Within the Transfer-Associated Structures.___ 3-11

3.2.1.3.2.1.1 Leak Detection Systems for Transfer-Associated Structures.___ 3-12

3.2.1.3.2.1.2 Process Pit and Cover Block Material Compatibility.__ 3-12

3.2.1.3.2.1.3 Eliminate Direct Spray Leakage Paths.____ 3-12

3.2.1.3.2.1.4 Confine Direct Spray Leaks Above Grade.___ 3-12

3.2.1.3.2.2 Contain Leakage Within Transfer Piping Encasement.__ 3-12

3.2.1.3.2.2.1 Pipe Encasement Capacity.______ 3-12

3.2.1.3.2.2.2 Encasement Piping Extension.__ 3-12 
3.2.1.3.2.2.3 Channel Waste from Primary Pipe.

3.2.1.3.2.2.4 Encasement Pipe Design Pressure.

3.2.1.3.2.3 Detect Leak in Transfer Associated Structures.

3.2.1.3.2.3.1 Leak Detector Capability.

3.2.1.3.2.3.2 Leak Detection System Operation.___ 3-13

3.2.2 Physical.

3.2.2.1 Dome Loading.

3.2.2.2 Dome Loading Controls.

3.2.3 Reliability, Maintainability, and Availability.

3.2.3.1 Design Life.

3.2.3.2 Maintenance.

3.2.3.2.1 Maintenance.

3.2.3.2.2 Testing.

3.2.3.2.3 Maintainability.

3.2.3.2.4 Non-Interruption of Operation.

3.2.3.3 Fault Detection/Fault Isolation.

3.2.3.4 Calibration.

3.2.4 Environmental Conditions.

3.2.4.1 Natural Environments.

3.2.4.1.1 Temperature.

3.2.4.1.2 Relative Humidity

3.2.4.1.3 Surface Precipitation

3.2.4.1.4 Sand and Dust.

3.2.4.1.5 Natural Loads.

3.2.4.1.5.1 Wind Loading.

3.2.4.1.5.2 Earthquake Loads.

3.2.4.1.5.3 Ashfall Loads.

3.2.4.1.6 Solar Radiation.

3.2.4.1.7 Lightning.

3.2.4.2 Induced Environments.

3.2.4.2.1 Radiation and Chemical.

3.2.4.2.2 Vibration.

3.2.5 Flexibility and Expansion.

3.2.5.1 Waste Transfer System Flexibility.

3.3 Design and Construction.

3.3.1 Materials, Processes, and Design Practices.__ 3-16

3.3.1.1 Corrosion Prevention and Control.___ 3-16

$\begin{array}{lll}\text { 3.3.1.1.1 Cathodic System Protection.___ 3-17 } & \text { 3.1 }\end{array}$

$\begin{array}{lll}\text { 3.3.1.1.2 Cathodic System Calibration._3-17 } & \text { 3.17 }\end{array}$

3.3.1.2 Secondary Containment Monitors._ 3-17

3.3.1.2.1 Hazardous Release Detection._ 3-17

3.3.1.2.2 Accumulated Liquid Detection.__ 3-17

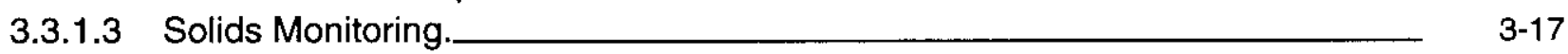

3.3.1.3.1 Monitoring/Sampling.__ 3-17

$\begin{array}{ll}\text { 3.3.1.4 Controls._ 3-17 } & \text { 3-17 }\end{array}$

3.3.1.4.1 Spill Prevention Controls.___ 3-17 
3.3.1.4.2 Collection of Releases.

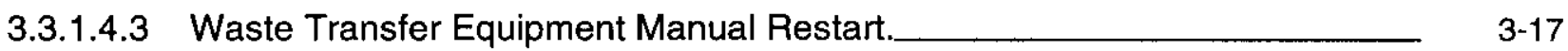

$\begin{array}{lll}\text { 3.3.1.5 Ancillary Equipment Support/Protection.__ 3-17 } & \text { 3-17 }\end{array}$

$\begin{array}{lll}\text { 3.3.1.6 Power Systems._ 3-17 } & \text { 3.17 }\end{array}$

$\begin{array}{lll}\text { 3.3.1.7 Other Electrical.___ 3-17 } & \text { 3.1 }\end{array}$

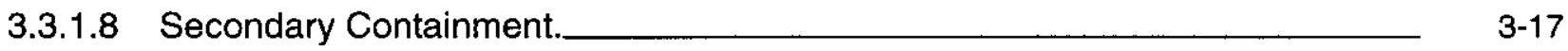

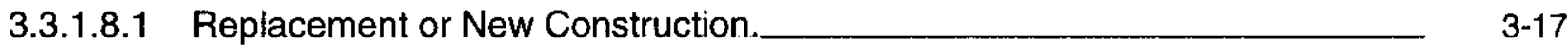

$\begin{array}{lll}\text { 3.3.1.8.2 Ancillary Equipment.__ 3-18 } & \text { 3-18 }\end{array}$

$\begin{array}{lll}\text { 3.3.1.8.3 Materials._ } & \text { 3-18 }\end{array}$

$\begin{array}{lll}\text { 3.3.1.8.4 Structure._ } & \text { 3-18 }\end{array}$

$\begin{array}{lll}\text { 3.3.1.8.5 Placement._ 3-18 } & \text { 3. }\end{array}$

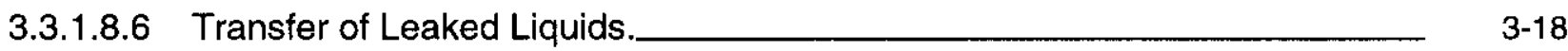

3.3.1.9 Radiological and Hazardous Material Protection.__ 3-18

3.3.1.9.1 Optimization Methods._ 3-18

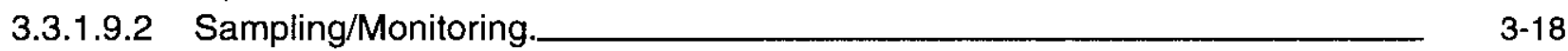

3.3.1.9.3 Liquid Radioactive Waste Systems.__ 3-18

3.3.1.10 Pump, Valve, Sample Connections._3-18

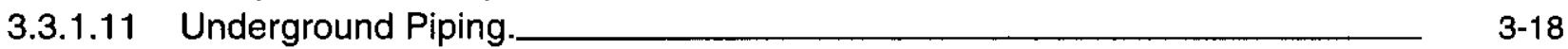

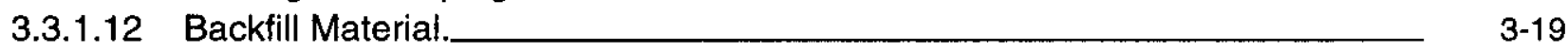

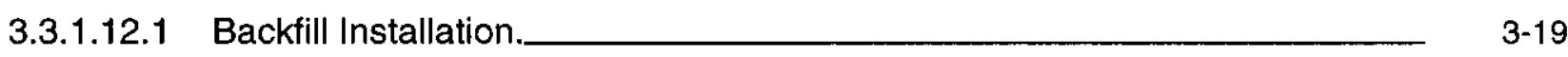

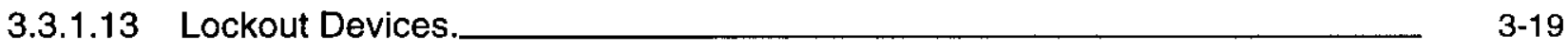

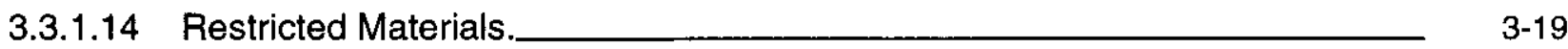

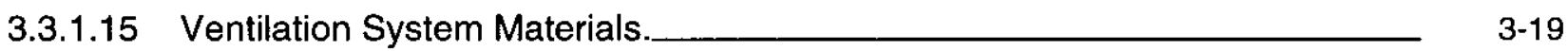

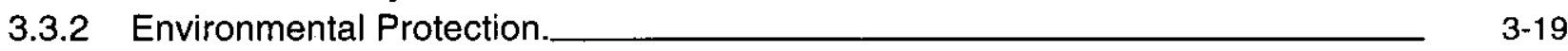

3.3.2.1 System Dose Equivalent.____ 3-19

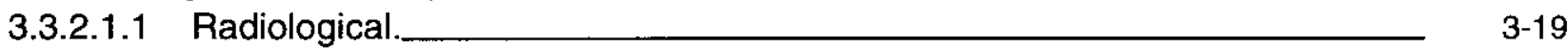

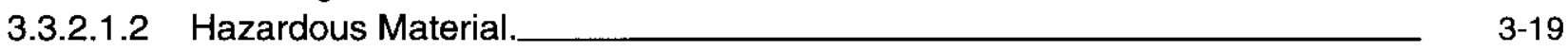

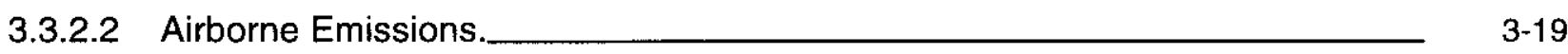

$\begin{array}{lll}\text { 3.3.2.2.1 Radiological.__ } & \text { 3-19 }\end{array}$

3.3.2.2.1.1 Radionuclide Emissions.___ 3-19

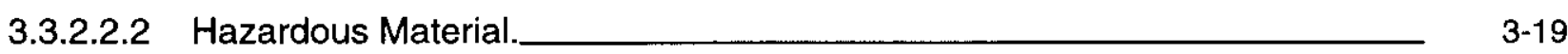

$\begin{array}{lll}\text { 3.3.2.2.2.1 Toxic Air Pollutants._ } & 3-20\end{array}$

$\begin{array}{lll}\text { 3.3.2.3 Ventilation/Filtration Systems._ } & 3-20\end{array}$

$\begin{array}{lll}\text { 3.3.2.4 Ventilation Airborne Releases._ } & 3-20\end{array}$

3.3.2.5 Point Source Emission Rates._ 3-20

$\begin{array}{lll}\text { 3.3.2.6 Water Discharge.___ 3-20 } & 3.20\end{array}$

3.3.2.7 Liquid Effluent Discharge.__ 3-20

$\begin{array}{ll}\text { 3.3.2.8 Oil-Filled Equipment.__ 3-20 } & 3.20\end{array}$

$\begin{array}{ll}\text { 3.3.3 Interchangeability._ 3-20 } & 3.20\end{array}$

$\begin{array}{lll}3.3 .4 \text { Safety.— } & 3-20\end{array}$

$\begin{array}{ll}\text { 3.3.4.1 Personnel Safety._ } & \text { 3-20 }\end{array}$

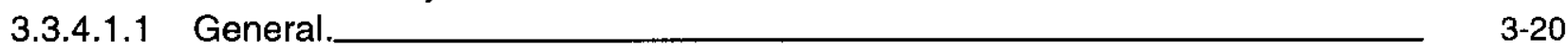

3.3.4.1.2 Continuous Air Monitors.___ 3-21

3.3.4.1.3 Occupational Exposure Limits._ 3-21

$\begin{array}{lll}\text { 3.3.4.1.4 Air Monitoring Systems.__- 3-21 } & \text { 3. }\end{array}$

3.3.4.1.5 Air Monitors Calibration.__ 3-21 
3.3.4.1.6 Air Monitor.

3.3.4.1.7 Central Radiation Monitoring and Alarm Readout.__ 3-21

3.3.4.1.8 Controls to Limit Airborne Radioactivity.__ 3-21

3.3.4.1.9 Preliminary Shielding Design Criteria.__ 3-21

3.3.4.1.9.1 Controlling Personnel Exposure.___ 3-21

3.3.4.1.9.2 Shield Design Criteria Table.__ 3-21

3.3.4.2 System Safety.___ 3-22

3.3.4.2.1 Safety Items (Structures, Systems and Components).___ 3-22

3.3.4.2.1.1 Engineering Evaluation for Safety Class and Safety Significant Systems._ 3-23

3.3.4.2.2 Flammable Gas.______ 3-23

3.3.5 Human Engineering.____ 3-23

3.3.5.1 Human Dimension Consideration.____ 3-23

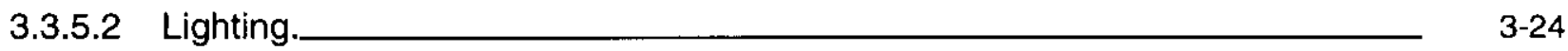

3.3.5.3 Noise._ 3-24

3.3.5.4 Component Arrangement.___ 3-24

3.3.5.5 Display Devices.__ 3-24

3.3.5.6 System Controls.__ 3-24

3.3.5.7 Component Controls.___ 3-24

3.3.5.8 Warning and Annunciator Systems.____ 3-24

3.3.5.9 Communication Systems.___ 3-24

$\begin{array}{lll}\text { 3.3.5.10 Labels._ 3-24 } & \text { Lab }\end{array}$

3.3.6 System Security.___ 3-24

3.4 Documentation._- 3-24

3.5 Logistics._ 3-25

$\begin{array}{lll}\text { 3.5.1 Maintenance and Operation.__ 3-25 } & \text { 3-25 }\end{array}$

3.5.1.1 Fully Remote Maintenance and Operation.__ 3-25

3.5.1.2 Limited Contact Maintenance and Operation.__ 3-25

3.5.1.3 Full Contact Maintenance and Operation.__ 3-25

3.5.2 Waste Handling, Storage, and Disposal.__ 3-25

3.5.3 Asbestos-Containing Materials.__ 3-25

3.5.4 Polychlorinated Biphenyls (PCBs).__ 3-25

3.5.5 Supply/Support.__ 3-25

3.5.6 Transportation Hazardous Materials.__ 3-25

3.6 Personnel and Training.__ 3-25

3.6.1 Personnel._ 3-25

3.6.2 Training._ 3-26

$\begin{array}{lll}3.7 & \text { Characteristics of Specific Elements.__ 3-26 }\end{array}$

3.7.1 Primary Ventilation Train Filter Instrumentation.___ 3-26

3.7.2 Waste Transfer Leak Detection.___ 3-26

3.7.3 Waste Transfer Routing Verification.___ 3-26

3.7.4 Master Pump Shutdown System._- 3-26

3.7.5 Annunciated Signals and Alarm Displays.___ 3-26

3.7.6 TMACS Alarm Signal Routing.__ 3-26

3.7.7 Pit/Diversion Box Protective Coating__ 3-26

3.7.8 Manifold Jumper/Valve Operating System___ 3-26

3.7.9 Waste Transfer Pipe Lines.______ 3-26 
3.7.10 Vent/Heater Control Panel.

3.7.11 Backup Power System.

3.7.12 Auxiliary Electrical Power.

3.7.13 Spare Circuit Breakers.

3.7.14 Cathodic Protection System.

3.7.15 DCRT Annulus Leak Detection.

3.7.16 Valve Position Indicators

3.7.17 Freeze Protection.

4 SYSTEM QUALIFICATION PROVISIONS_ 4-1

4.1 General._ 4-1

4.1.1 Responsibility for Inspections.___ 4-1

4.1.2 Special Tests and Examinations.__ 4-1

4.2 Quality Conformance Inspections.__ 4-1

5 NOTES_L 5-1

5.1 Definitions._ 5-1

5.1.1 Abnormal._ 5-1

5.1.2 Characterize Waste._ 5-1

5.1.3 Concentrate Waste.___ 5-1

5.1.4 Design Life.__ 5-1

5.1.5 Double-Shell Tanks.__ 5-1

5.1.6 Emergency Mission Records.__ 5-1

5.1.7 General Management Record.________ 5-1

5.1.8 Industrial Records.___ 5-1

5.1.9 Retrieve Waste.___ 5-2

5.1.10 Safety Class Structures.__ 5-2

5.1.11 Safety Classification.__ 5-5

5.1.12 Secondary Containment.___ 5-5

5.1.13 Single-Shell Tanks.__ 5-5

5.1.14 Store Waste._ 5-5

5.1.15 System._ 5-5

5.1.16 Tank Intrusion______ 5-5

5.1.17 Transfer Waste.__ 5-5

5.1.18 Project/Plan Definitions.__ 5-5

5.1.18.1 W-211 Initial Tank Retrieval System.__ 5-5

5.1.18.2 W-519, Privatization Infrastructure Phase 1 Support System._ 5-6

5.1.18.3 Project W-521, Waste Feed Delivery._____ 5-6

5.1.18.4 Project W-522, DST Retrieval.__ 5-6

5.2 Abbreviations and Acronyms._ $5-877$ 
HNF-SD-W314-DRD-001, Rev. 2

\section{List of Tables}

1-1 Tank Farm Grouping.

3-1 Project W-314 Definition.

3-2 200 East Area Project Interface Control Document List

3-3 200 West Area Project Interface Control Document List

3-4 Project W-211 Project Interface Control Document List

3-5 Project W-519 Project Interface Control Document List

3-6 Project W-521 Project Interface Control Document List

3-7 Project W-522 Project Interface Control Document List

3-8 Authorized Dome Loads

3-9 Shield Design Criteria

4-1 Quality Conformance Inspection Matrix_ 4-2

5-1 Safety Performance Category 
HNF-SD-W314-DRD-001, Rev. 2

\section{SCOPE}

\subsection{Identification.}

Program: River Protection Project (RPP)

Project: Tank Farm Restoration and Safe Operations (Project W-314)

Elements: Selected Tank Farm instrumentation and displays, master pump shutdown; selected DST \& DCRT ventilation and cooling system elements; selected waste transfer system elements; and selected electrical distribution system elements.

\subsection{System Overview.}

The tank farm system at Hanford Site currently consists of 149 single shell tanks and 28 double shell tanks with associated facilities and equipment, located in 18 separate groupings. Each grouping is known as a tank farm. They are located in the areas designated as 200 West and 200 East. Table 1-1 shows the number of tanks in each farm. The farms are connected together through a transfer system consisting of piping, diversion boxes, Double Contained Receiver Tanks (DCRT) and other miscellaneous facilities and elements. The tank farm system also connects to a series of processing plants which generate radioactive and hazardous wastes. The primary functions of the tank farm system are to store, transfer, concentrate, and characterize radioactive and hazardous waste generated at Hanford, until the waste can be safely retrieved, processed and dispositioned. The systems provided by Project W-314 support the store and transfer waste functions. The system elements to be upgraded by Project W-314 are identified in Section 3.1.

\subsection{Document Overview.}

This document sets forth functional requirements, performance requirements, and design constraints for the tank farm system elements identified in Section 3.1. These requirements shall be used to develop the Design Requirements Baseline for those system elements. 
HNF-SD-W314-DRD-001, Rev. 2

Table 1-1 Tank Farm Grouping.

\begin{tabular}{|c|c|c|c|}
\hline \multicolumn{4}{|c|}{ Hanford Site Tank Farms } \\
\hline Area & Tank Farm & Single-Shell & Double-Shell \\
\hline 200 West & $T$ & 16 & 0 \\
\cline { 2 - 4 } & $T \mathrm{TX}$ & 18 & 0 \\
\cline { 2 - 4 } & $\mathrm{TY}$ & 6 & 0 \\
\cline { 2 - 4 } & $\mathrm{U}$ & 16 & 0 \\
\cline { 2 - 4 } & $\mathrm{S}$ & 12 & 0 \\
\cline { 2 - 4 } & $\mathrm{SX}$ & 15 & 0 \\
\hline \multirow{6}{*}{ 200 East } & $\mathrm{SY}$ & 0 & 3 \\
\cline { 2 - 4 } & $\mathrm{A}$ & 6 & 0 \\
\cline { 2 - 4 } & $\mathrm{AN}$ & 0 & 7 \\
\cline { 2 - 4 } & $\mathrm{AP}$ & 0 & 8 \\
\cline { 2 - 4 } & $\mathrm{AW}$ & 0 & 6 \\
\cline { 2 - 4 } & $\mathrm{AX}$ & 4 & 0 \\
\cline { 2 - 4 } & $\mathrm{AY}$ & 0 & 2 \\
\cline { 2 - 4 } & $\mathrm{AZ}$ & 0 & 2 \\
\cline { 2 - 4 } & $\mathrm{C}$ & 16 & 0 \\
\cline { 2 - 4 } & $\mathrm{B}$ & 16 & 0 \\
\cline { 2 - 4 } & $\mathrm{BX}$ & 12 & 28 \\
\cline { 2 - 4 } & $\mathrm{BY}$ & 12 & \\
\hline Total Tanks & & 149 & 0 \\
\hline
\end{tabular}




\section{APPLICABLE DOCUMENTS}

\subsection{COMPLIANCE DOCUMENTS}

The following documents of the exact issue shown form a part of the requirements of this DRD to the extent specified herein. In the event of a conflict between the documents referenced herein and the contents of this DRD, due to subsequent compliance document interpretations or revisions, the requirements of this DRD shall be considered a superseding requirement until required DRD changes are instituted through the formal change control process.

\section{Regulations/Standards:}

DOE Documents

DOE 5400.1

DOE 5400.5

DOE 5480.20A

DOE 5820.2A

DOE 6430.1A

DOE O 420.1

Code of Federal Regulations(CFR)

29 CFR 1910

40 CFR 141

40 CFR 264
General Environmental Protection Program Requirements - 6/29/90

Radiation Protection of the Public and the Environment - 1/7/93

Personnel Selection, Qualification, Training, and Staffing Requirements at DOE Reactor and Non-Reactor Nuclear Facilities $1 / 15 / 94$

Radioactive Waste Management - 9/26/88

United States Department of Energy General Design Criteria - 6 April 89

Facility Safety, Fire Protection - 12/10/98

Occupational Safety and Health Standards $7 / 1 / 98$

National Primary Drinking Water

Regulations - 7/1/98

Standards for Owners and Operators of Hazardous Waste Treatment, Storage, and Disposal Facilities - Jul. 98 
40 CFR 265

40 CFR 52

40 CFR 61

40 CFR 761
Interim Steps for Owners and Operators of Hazardous Waste Treatment, Storage, and Disposal Facilities - Jul. 98

Approval and Promulgation of Implementation Plans - 7/1/98

National Emission Standards for Hazardous Air Pollutants - Jul. 98

Polychlorinated Biphenyls (PCBs) manufacturing, processing, distribution in commerce, and use prohibitions - 7/1/98

\section{Other Documents:}

Project Interface Control Documents (PICDs) (generated by Project W-314) (Draft)

W314-PICD-200-AREA

W314-PICD-200-EAST

W314-PICD-200-WEST

W314-PICD-241-AY/AZ

W314-PICD-241A

W314-PICD-241AN

W314-PICD-241AP

W314-PICD-241AW

W314-PICD-241BY

W314-PICD-241C

W314-PICD-241SY

W314-PICD-241U

W314-PICD-242A-EVAP

W314-PICD-244S-DCRT
Interfaces with 200 Area Projects - 12/95

200 East - 12/95

200 West $-12 / 95$

AY/AZ Tank Farm Upgrades - 12/95

A Tank Farm Upgrades - 12/95

AN Tank Farm Upgrades - 12/95

AP Tank Farm Upgrades - 12/95

AW Tank Farm Upgrades - 12/95

BY Tank Farm Upgrades - 12/95

C Tank Farm Upgrades - 12/95

SY Tank Farm Upgrades - 12/95

U Tank Farm Upgrades - 12/95

Interfaces at the 242-A Evaporator - 12/95

Interfaces at the 244-S DCRT 
Hanford Procedures (HNF-PROs)

HNF-PRO-097

HNF-PRO-154

HNF-PRO-210

HNF-PRO-211

HNF-PRO-222

HNF-PRO-224

HNF-PRO-229

HNF-PRO-231

HNF-PRO-232

HNF-PRO-233

HNF-PRO-450

HNF-PRO-456

HNF-PRO-704

HNF-PRO-709
Engineering Design and Evaluation, Rev. 0

Responsibilities and Procedures for All Hazardous Materials, Rev. 0

Records Management Program Standards, Rev. 2

Public Information Repository and Administrative Record Files, Rev. 1

Quality Assurance Records Standards, Rev. 1

Document Control Program Standards, Rev. 2

Technical Procedure Standard, Rev. 3

Correspondance Control Standards, Rev. 1

Project Files Management, Rev. 1

Review and Approval of Documents, Rev. 0 Air Quality -- Radioactive Emissions, Rev. 0

Water Quality Program, Rev. 0

Hazard and Accident Analysis Process, Rev. 0

Preparation and Control Standards for Engineering Drawings, Rev. 1

National Electrical Safety Code - 1984

Code on Nuclear Air and Gas Treatment $1 / 31 / 97$

Process Piping - 1996

Nuclear Power Plant Air Cleaning Units and Components - R1996 
ASME N510

HNF-2937

HNF-AOP-97-1

HNF-IP-0842

HNF-SD-WM-SAR-067

HSRCM-1

NFPA 70

NUREG 0700

UCRL 15673

WAC $173-200$

WAC 173-303

WAC $173-400$

WAC $173-460$

WAC 246-247

WAC 246-290

WHC-SD-GN-DGS-30008
Testing of Nuclear Air Cleaning System R1995

Estimated Maximum Concentration of Radionuclides \& Chemical Analytes in Phase 1 \& Phase 2 Transfers, Rev. 0 , September 1999

Hanford Site Air Operating Permit

TWRS Administration

Tank Waste Remediation System Final Safety Analysis Report, Rev. 0

Hanford Site Radiological Control Manual, Rev. 2 - 12/9/94

National Fire Protection Association, National Electric Code - 1993

Human System Interface Design Review Guideline - June 1996

Human Factors Design Guidelines for Maintainability of DOE Nuclear Facilities June 1985

Water Quality Standards for Ground Waters of State of Washington - 1997

Washington Dangerous Waste Regulations $-1 / 98$

General Regulations for Air Pollution Sources - 1997

Controls for New Sources of Toxic Air Pollutants - 1/98

Radiation Protection-Air Emissions - 1997

Maximum Contaminant Level, Department of Health - 1997

Design Loads for New Underground DST and Associated Underground Process Piping, Rev. 0 


\subsection{REFERENCE DOCUMENTS}

The following documents listed are references which may help the understanding of DRD requirements. The applicable portions of these documents have been incorporated into the body of the DRD.

\section{Regulations/Standards:}

DOE Documents

DOE 5400.1

General Environmental Protection Program Requirements - 6/29/90

DOE 5400.5

Radiation Protection of the Public and the Environment - 1/7/93

DOE 5480.20A

Personnel Selection, Qualification, Training, and Staffing Requirements at DOE Reactor and Non-Reactor Nuclear Facilities $1 / 15 / 94$

DOE 5820.2A

Radioactive Waste Management - 9/26/88

DOE 6430.1A

United States Department of Energy

General Design Criteria - 6 April 89

DOE/EH-0173T

Environmental Regulatory Guide for Radiological Effluent Monitoring and Environmental Surveillance - 1/91

Code of Federal Regulations(CFR)

10 CFR 835

29 CFR 1910

40 CFR 141

40 CFR 191
Occupational Radiation Protection - Jan. 99

Occupational Safety and Health Standards $7 / 1 / 98$

National Primary Drinking Water

Regulations - 7/1/98

Environmental Radiation Protection 
40 CFR 264

40 CFR 265

40 CFR 280

40 CFR 52

40 CFR 61

40 CFR 761

Washington State Regulations

WAC 173-303

WAC $173-460$

WAC 246-247

WAC 246-290
Standards for Management and Disposal of Spent Nuclear Fuel, High-Level and Transuranic Radioactive Wastes

Standards for Owners and Operators of Hazardous Waste Treatment, Storage, and Disposal Facilities - Jul. 98

Interim Steps for Owners and Operators of Hazardous Waste Treatment, Storage, and Disposal Facilities - Jul. 98

Technical Standards and Corrective Action Requirements for Owners and Operators of Underground Storage Tanks (UST)

Approval and Promulgation of Implementation Plans - 7/1/98

National Emission Standards for Hazardous Air Pollutants - Jul. 98

Polychlorinated Biphenyls (PCBs) manufacturing, processing, distribution in commerce, and use prohibitions - 7/1/98

Washington Dangerous Waste Regulations $-1 / 98$

Controls for New Sources of Toxic Air Pollutants - 1/98

Radiation Protection-Air Emissions - 1997

Maximum Contaminant Level, Department of Health - 1997

\section{Other Documents:}

Project W-314 Generated Document

WHC-SD-W314-DRD-001

Preliminary Design Requirements Document for Project W-314, Tank Farm Restoration and Safe Operations, Rev. 0 - 
February 1995

Other

ASME AG-1b-1997

ASME B31.3

Clean Air Act, Part B

HNF-5049

HNF-IP-0842

HNF-PRO-097

HNF-PRO-154

HNF-PRO-156

HNF-PRO-157

HNF-PRO-158

HNF-PRO-163

HNF-PRO-166

HNF-PRO-1819

HNF-PRO-210

HNF-PRO-211

HNF-PRO-222
Code on Nuclear Air and Gas Treatment $1 / 31 / 97$

Process Piping - 1996

Requirements Derivation for W-314 Preliminary Design Requirements

Document Rev. 2, September 1999

TWRS Administration

Engineering Design and Evaluation, Rev. 0

Responsibilities and Procedures for All Hazardous Materials, Rev. 0

Nonradioactive Hazardous Materials/Hazardous Waste $(\mathrm{HM} / \mathrm{HW})$ Shipments, Rev. 0

Radioactive Hazardous Material/Waste Shipments, Rev. 0

Shipping and Receiving in the 1100 Area, Rev. 0

Documentation and Record Keeping, Rev. 0

Transportation Safety Training

Requirements, Rev. 0

PHMC Engineering Requirements, Rev. 3

Records Management Program Standards, Rev. 2

Public Information Repository and Administrative Record Files, Rev. 1

Quality Assurance Records Standards, Rev. 1 
HNF-PRO-224

HNF-PRO-229

HNF-PRO-231

HNF-PRO-232

HNF-PRO-233

HNF-PRO-2364

HNF-PRO-430

HNF-PRO-450

HNF-PRO-456

HNF-PRO-462

HNF-PRO-709

HNF-SD-WM-SAR-067

HNF-SD-WM-TRD-007

HNF-SD-WM-TSR-006

HSRCM-1

OSD-T-151-00007

OSD-T-151-00013

OSD-T-151-00017

W314-PICD-200-AREA
Document Control Program Standards, Rev. 2

Technical Procedure Standard, Rev. 3

Correspondance Control Standards, Rev. 1

Project Files Management, Rev. 1

Review and Approval of Documents, Rev. 0

Radioactive Airborne Effluent Sampling, Rev. 0

Safety Analysis Program, Rev. 1

Air Quality -- Radioactive Emissions, Rev. 0

Water Quality Program, Rev. 0

Pollution Prevention, Rev. 0

Preparation and Control Standards for Engineering Drawings, Rev. 1

Tank Waste Remediation System Final Safety Analysis Report, Rev. 0

System Specification for the Double Shell Tank System, Rev. E

Tank Waste Remediation System Technical Safety Requirements, Rev. OU

Hanford Site Radiological Control Manual, Rev. 2 - 12/9/94

Operating Specifications for the 241-AN, AP, AW, AY, AZ and SY Tank Farms, Rev $\mathrm{H}-13-7 / 28 / 95$

Operating Specifications for Single-Shell Waste Storage Tanks, Rev D-5, 8/11/95

Operating Specification for Aging Waste Operations in 241-AY and 241-AZ, Rev. D $6 / 19 / 95$

Interfaces with 200 Area Projects - 12/95 


\begin{tabular}{|c|c|}
\hline W314-PICD-200-EAST & 200 East $-12 / 95$ \\
\hline W314-PICD-200-WEST & 200 West - 12/95 \\
\hline W314-PICD-241-AY/AZ & AY/AZ Tank Farm Upgrades - 12/95 \\
\hline W314-PICD-241A & A Tank Farm Upgrades - 12/95 \\
\hline W314-PICD-241AN & AN Tank Farm Upgrades - 12/95 \\
\hline W314-PICD-241AP & AP Tank Farm Upgrades - 12/95 \\
\hline W314-PICD-241AW & AW Tank Farm Upgrades - $12 / 95$ \\
\hline W314-PICD-241BY & BY Tank Farm Upgrades - 12/95 \\
\hline W314-PICD-241C & C Tank Farm Upgrades - 12/95 \\
\hline W314-PICD-241SY & SY Tank Farm Upgrades - 12/95 \\
\hline W314-PICD-241U & U Tank Farm Upgrades - 12/95 \\
\hline W314-PICD-242A-EVAP & Interfaces at the 242-A Evaporator - 12/95 \\
\hline W314-PICD-244S-DCRT & Interfaces at the 244-S DCRT \\
\hline WHC-SD-GN-DGS-30011 & Radiological Design Guide - 9/27/94 \\
\hline WHC-SD-HS-SAR-010 & Aging Waste Facility Safety Analysis Report \\
\hline WHC-SD-W314-CSD-001 & $\begin{array}{l}\text { Project W-314 System Environment Policy - } \\
\text { August } 1995\end{array}$ \\
\hline WHC-SD-W314-RPT-003 & $\begin{array}{l}\text { Tank Farm Restoration and Safe } \\
\text { Operations, Project W-314, Upgrade Scope } \\
\text { Summary Report - February 26, } 1996\end{array}$ \\
\hline WHC-SD-WM-OSR-016 & $\begin{array}{l}\text { Double Shell Tank Interim Operational } \\
\text { Safety Requirements }\end{array}$ \\
\hline
\end{tabular}




\section{REQUIREMENTS}

\subsection{Project Definition.}

Project W-314 shall affect the existing tank farm facilities as indicated by Table 3-1.

Table 3-1 Project W-314 Definition.

\begin{tabular}{|c|c|}
\hline Project W-314 Elements & Tank Farm Facilities Affected \\
\hline \multicolumn{2}{|l|}{ Instrumentation: } \\
\hline Waste storage instrumentation & \begin{tabular}{|l} 
All DSTs \\
- Tank waste monitors \\
- - Primary tank vapor space pressure \\
- - Connect existing and new alarms to central \\
monitoring station \\
244-S DCRT: \\
- Annulus leak detectors \\
- Tank Waste Monitors \\
- - Temperature \\
- Primary tank vapor space pressure \\
Gaseous Effluent Monitoring System in AN, AP, and AW \\
Tank Farms primary ventilation exhaust stacks
\end{tabular} \\
\hline $\begin{array}{l}\text { Primary ventilation train pre-filter } \\
\text { and HEPA filter monitors }\end{array}$ & $\begin{aligned} \text { AN, AW, and AP Farms and 244-S DCRT: } \\
-\quad \text { differential pressures } \\
-\quad \text { exhaust temperatures } \\
-\quad \text { exhaust heater differential pressure } \\
\end{aligned}$ \\
\hline Waste transfer instrumentation & $\begin{array}{l}\text { Existing primary pipeline leak detectors in selected DST } \\
\text { Tank Farms and 244-S DCRT, transfer pit and pipeline } \\
\text { encasements. } \\
\text { Leak detection for new piping. } \\
\end{array}$ \\
\hline $\begin{array}{l}\text { Master Pump Shutdown System } \\
\text { (MPSS) }\end{array}$ & Selected instrumentation in DST Tank Farms \\
\hline Signal routing and displays & $\begin{array}{l}\text { DST Tank Farm "Game-Well" remote alarm monitors and } \\
\text { alarm displays. } \\
\text { Selected AW alarms to 242-A DCS }\end{array}$ \\
\hline Valve Position Indicators (VPIs) & $\begin{array}{l}\text { Valve Pits AN-A, AN-B, 241-AP, AW-A, AW-B, Pump Pits } \\
\text { AN-01A, AN-04A, AY-02A, AZ-01A, and AZ-02A }\end{array}$ \\
\hline Ventilation Elements: & \\
\hline
\end{tabular}




\begin{tabular}{|c|c|}
\hline Project W-314 Elements & Tank Farm Facilities Affected \\
\hline Ventilation and cooling & $\begin{array}{l}\text { AN, AP, and AW Tank Farms } \\
-\quad \text { Primary exhaust system and stack } \\
-\quad \text { Primary ventilation inlet station (AP Tank Farm } \\
\text { - } \quad \text { Exis) } \\
\text { Upgrade primary ventilation system in the 244-S DCRT. } \\
\text { Upgrade the annulus ventilation in SY Tank Farm } \\
-\quad \text { Annulus exhaust system } \\
\text { (Note that ventilation systems include seal pots, drainage } \\
\text { systems, and filtration systems.) }\end{array}$ \\
\hline \multicolumn{2}{|l|}{ Waste Transfer Elements: } \\
\hline Protective coating & $\begin{array}{l}\text { Existing Special Protective Coating (SPC) in selected pits } \\
\text { will be assessed and repaired as necessary to facilitate } \\
\text { future pit clean-up. }\end{array}$ \\
\hline $\begin{array}{l}\text { Manifold jumper arrangements and } \\
\text { valve operating system }\end{array}$ & Selected valve and pump pits \\
\hline Valve Pits & $\begin{array}{l}\text { Installation of a new AZ Valve Pit to facilitate waste } \\
\text { transfers in support of Waste Feed Delivery program. }\end{array}$ \\
\hline Piping & $\begin{array}{l}\text { New transfer lines: } \\
\text { AN-04A to AP-04D; } \\
\text { AN-01A to new AZ valve pit; } \\
\text { AZ valve pit to AP Farm; } \\
\text { extension of SNL-3150 to AN-01A; } \\
\text { extension of SLL-3160 to AN-04D; } \\
\text { AZ-01A to AZ-02A; } \\
\text { AY-01A to AY-02A; } \\
\text { AZ-01A to AZ valve pit; } \\
\text { AY-02A to AZ valve pit; } \\
\text { New AZ valve pit to Privatization Contractor (PC) } \\
\text { interface; } \\
\text { Connecting LIQW-702 to SN-220, bypassing A-A Valve } \\
\text { Pit }\end{array}$ \\
\hline \multicolumn{2}{|l|}{ Electrical Distribution: } \\
\hline $\begin{array}{l}\text { Selected Motor Control Centers } \\
\text { (MCCs) }\end{array}$ & AY and $A Z$ Tank Farms. \\
\hline $\begin{array}{l}\text { Backup power (Diesel receptacles } \\
\text { only) }\end{array}$ & $\begin{array}{l}\text { Primary ventilation system and stack monitors for } \\
241-A N, A P, A W \text { and SY Tank Farms }\end{array}$ \\
\hline Mini-power stations (240/110Vac) & DST Tank Farms, and 244-S DCRT. \\
\hline Spare main circuit breakers & 241-AN and 241-AW Tank Farms. \\
\hline Cathodic protection system & $\begin{array}{l}\text { All new piping without other means of protection, as } \\
\text { required. }\end{array}$ \\
\hline Freeze protection & Seal pots and drainage systems installed by $W-314$. \\
\hline
\end{tabular}




\subsubsection{Systems Elements Purpose.}

Each system element described in Table 3-1 must operate during waste storage, waste transfer, waste characterization and concentration operations as specified herein.

\subsubsection{W-314 System Elements.}

Tank farm system elements consisting of discrete selected items of the : (a) DST and DCRT (244-S) Ventilation Systems; (b) 200 Area tank farm Electrical Power System; (c) the DST Waste Transfer System; and (d) tank farm instrumentation and displays.

\subsubsection{Instrumentation and Displays.}

The structures, systems and components, including software and personnel, necessary to monitor and display the physical parameters and the behavior of tank farm storage and transfer operations. Monitoring and control may be manually or automatically performed.

\subsubsection{Ventilation and Cooling System.}

Selected structures, systems and components necessary to control and mitigate the collection of hazardous gasses and particulate effluents within the 200 Area DSTs, and the 244-S DCRT, the discharge of hazardous gaseous or particulate effluents to the environment, and the effects of excessive heat generation within said tanks.

3.1.1.4 W-314 Transfer System Elements. The discrete elements of the DST waste transfer system that include protective coating of the pump pits and valve pits/diversion boxes; manifold jumper arrangements and valve operating system for selected valve pits and pump pits; and selected new pipelines (see Table 3-1).

3.1.1.5 Electrical Distribution Elements. The discrete elements of the tank farm electrical distribution system, which includes: (a) selected MCCs; (b) backup power connection for primary ventilation and stack monitors in AN, AP and AW farms; (c) mini power stations for instrumentation in the DST Farms and 244-S DCRT; (d) cathodic protection (as required) for new Tank Farm piping; and (e) selected circuit breakers (see Table 3-1).

\subsubsection{Interface Definition.}

\subsubsection{Hanford Site Utilities.}

Each system shall interface with the Hanford Site Utilities in accordance with Project Interface Control Document (PICD) W314-PICD-200-AREA (Interfaces with 200 Area Projects).

\subsubsection{Tank Farm System - 200 East.}

Each system shall interface with Area 200 East Tank Farm elements in accordance with the PICDs listed in Table 3-2. 
Table 3-2 200 East Area Project Interface Control Document List

\begin{tabular}{|c|c|c|}
\hline Area/Facility & Controlling PICD & Comments \\
\hline 200 East Area & W314-PICD-200-EAST & $\begin{array}{l}\text { This document } \\
\text { encompasses scope, upper } \\
\text { level interface details and } \\
\text { associated issues for } \\
\text { Instrumentation and } \\
\text { Control, Electrical, } \\
\text { Ventilation and Cooling, } \\
\text { and Waste Transfer } \\
\text { Systems for all of the } 200 \\
\text { East Area. }\end{array}$ \\
\hline 241-AN Tank Farm & W314-PICD-241AN & \multirow{3}{*}{$\begin{array}{l}\text { These documents } \\
\text { encompass scope, upper } \\
\text { level interfaces and } \\
\text { associated issues for } \\
\text { Instrumentation \& Control, } \\
\text { Electrical, Ventilation and } \\
\text { Cooling, and Waste } \\
\text { Transfer system elements. } \\
\end{array}$} \\
\hline 241-AP Tank Farm & W314-PICD-241AP & \\
\hline 241-AW Tank Farm & W314-PICD-241AW & \\
\hline 241-AY/AZ Tank Farm & W314-PICD-241-AY/AZ & \multirow[b]{2}{*}{$\begin{array}{l}\text { These documents } \\
\text { encompass scope, upper } \\
\text { level interfaces and } \\
\text { associated issues for } \\
\text { Electrical, Waste Transfer, } \\
\text { Instrumentation and Control } \\
\text { System elements. }\end{array}$} \\
\hline 241-A Tank Farm & W314-PICD-241A & \\
\hline 241-BY Tank Farm & W314-PICD-241BY & \multirow{2}{*}{$\begin{array}{l}\text { These documents } \\
\text { encompass scope, upper } \\
\text { level interfaces and } \\
\text { associated issues for } \\
\text { Instrumentation and } \\
\text { Control. }\end{array}$} \\
\hline 241-C Tank Farm & W314-PICD-241C & \\
\hline 204-AR Unload Facility & \multirow[t]{2}{*}{ W314-PICD-200-EAST } & \multirow{3}{*}{$\begin{array}{l}\text { These documents } \\
\text { encompass scope, upper } \\
\text { level interfaces and } \\
\text { associated issues for } \\
\text { Instrumentation and Control } \\
\text { system elements. }\end{array}$} \\
\hline 244-AR Vault & & \\
\hline 242-A Evaporator & W314-PICD-242A-EVAP & \\
\hline
\end{tabular}

\subsubsection{Tank Farm System - 200 West.}

Each system shall interface with Area 200 West Tank Farm System elements in accordance with the PICDs listed in Table 3-3. 
Table 3-3 200 West Area Project Interface Control Document List

\begin{tabular}{|c|c|c|}
\hline Area/Facility & Controlling PICD & Comments \\
\hline 200 West Area & W314-PICD-200-WEST & $\begin{array}{l}\text { This document } \\
\text { encompasses scope, upper } \\
\text { level interfaces and } \\
\text { associated issues for } \\
\text { Instrumentation and } \\
\text { Control, Electrical, } \\
\text { Ventilation and Cooling, } \\
\text { and Waste Transfer } \\
\text { Systems elements for all of } \\
\text { the } 200 \text { West Area. }\end{array}$ \\
\hline 241-SY Tank Farm & W314-PICD-241SY & \multirow[b]{2}{*}{$\begin{array}{l}\text { These documents } \\
\text { encompass scope, upper } \\
\text { level interfaces and } \\
\text { associated issues for } \\
\text { Instrumentation \& Control, } \\
\text { Electrical, Ventilation and } \\
\text { Cooling, and Waste } \\
\text { Transfer system elements. }\end{array}$} \\
\hline 244-S DCRT & W314-PICD-244S-DCRT & \\
\hline 241-U Tank Farm & W314-PICD-241U & $\begin{array}{l}\text { This document } \\
\text { encompasses scope, upper } \\
\text { level interfaces and } \\
\text { associated issues for } \\
\text { Instrumentation and } \\
\text { Control. }\end{array}$ \\
\hline 242-T Evaporator & W314-PICD-200-WEST & $\begin{array}{l}\text { This document } \\
\text { encompasses scope, upper } \\
\text { level interfaces and } \\
\text { associated issues for } \\
\text { Instrumentation and Control } \\
\text { System elements. }\end{array}$ \\
\hline
\end{tabular}

\subsubsection{Project W-211 Initial Tank Retrieval System.}

Each system shall interface with the Project W-211 Initial Retrieval System in accordance with the PICDs listed in Table 3-4. Project W-314 shall exchange data with the Project W-211 system in support of tank waste retrieval. Project W-314 shall also provide pit coatings, leak detectors, valve position indications, and connection for the Project $W-211$ systems at various locations identified in lower level PICDs. 
Table 3-4 Project W-211 Project Interface Control Document List

\begin{tabular}{|l|l|l|}
\hline \multicolumn{1}{|c|}{ Area/Facility } & \multicolumn{1}{|c|}{ Controlling PICD } & \multicolumn{1}{c|}{ Comments } \\
\hline 241-AN Tank Farm & W314-PICD-241AN & $\begin{array}{l}\text { These documents } \\
\text { encompass scope, upper } \\
\text { level interfaces and } \\
\text { associated issues with } \\
\text { W-211 for Instrumentation } \\
\text { and Control, Ventilation and } \\
\text { Cooling, and Waste } \\
\text { Transfer. }\end{array}$ \\
\hline 241-SY Tank Farm & W314-PICD-241AW & $\begin{array}{l}\text { This document } \\
\text { encompasses scope, upper } \\
\text { level interfaces and } \\
\text { associated issues with } \\
\text { W-211 for Instrumentation } \\
\text { and Control, and Waste } \\
\text { Transfer. }\end{array}$ \\
\hline
\end{tabular}

\subsubsection{Project W-519, Privatization Infrastructure Phase 1 Support System.}

Each system shall interface with Project W-519, Privatization Infrastructure Phase 1 Support System, with the PICD listed in table 3-5. Project W-314 will coordinate with Project W-519 to prevent duplication of scope and prevent interference between projects.

Table 3-5 Project W-519 Project Interface Control Document List

\begin{tabular}{|c|c|c|}
\hline Area/Facility & Controlling PICD & Comments \\
\hline $200 E$ & W314-PICD-200-EAST & $\begin{array}{l}\text { This document } \\
\text { encompasses scope, upper } \\
\text { level interfaces, and } \\
\text { associated issues for } \\
\text { instrumentation and control, } \\
\text { ventilation and cooling, and } \\
\text { waste transfer. }\end{array}$ \\
\hline
\end{tabular}

\subsubsection{Project W-521, Waste Feed Delivery.}

Each system shall interface with Project W-521, Waste Feed Delivery, with the PICDs listed in table 3-6. Project W-314 will coordinate with Project W-521 to prevent duplication of scope and prevent interference between projects. 
Table 3-6 Project W-521 Project Interface Control Document List

\begin{tabular}{|c|c|c|}
\hline Area/Facility & Controlling PICD & Comments \\
\hline 241-AW Tank Farm & W314-PICD-241AW & \multirow{3}{*}{$\begin{array}{l}\text { These documents } \\
\text { encompass scope, upper } \\
\text { level interfaces, and } \\
\text { associated issues for } \\
\text { instrumentation and control, } \\
\text { ventilation and cooling, and } \\
\text { waste transfer. }\end{array}$} \\
\hline 241-AP Tank Farm & W314-PICD-241AP & \\
\hline 241-SY Tank Farm & W314-PICD-241SY & \\
\hline
\end{tabular}

\subsubsection{Project W-522, DST Retrieval.}

Each system shall interface with Project W-522, DST Retrieval, with the PICDs listed in table 3-7. Project W-314 will coordinate with Project W-522 to prevent duplication of scope and prevent interference between projects.

Table 3-7 Project W-522 Project Interface Control Document List

\begin{tabular}{|c|c|c|}
\hline Area/Facility & Controlling PICD & Comments \\
\hline 241-AN Tank Farm & W314-PICD-241AN & \multirow{4}{*}{$\begin{array}{l}\text { These documents } \\
\text { encompass scope, upper } \\
\text { level interfaces, and } \\
\text { associated issues for } \\
\text { instrumentation and control, } \\
\text { ventilation and cooling, and } \\
\text { waste transfer. }\end{array}$} \\
\hline 241-AW Tank Farm & W314-PICD-241AW & \\
\hline 241-SY Tank Farm & W314-PICD-241SY & \\
\hline 241-AY/AZ Tank Farms & W314-PICD-241AY/AZ & \\
\hline
\end{tabular}

3.1.2.8 Current Project List. A definitive list of all current projects providing Tank Farm upgrades are listed in Table 1 of the W-314 Project Interface Control Document associated with this DRD. This list provides status, document and contact reference for each project or workplan identified.

\subsection{Characteristics.}

\subsubsection{System Performance.}

The W-314 system elements shall meet the following performance characteristics to the extent specified herein.

3.2.1.1 DST Waste Storage. The W-314 system shall accomplish DST Waste Storage as follows:

3.2.1.1.1 Control DST Temperature. The temperature of the waste in the DST shall be controlled to prevent excessive stresses to the primary tank, structural degradation of the concrete shell, tank bumps and organic salt nitrate reactions. The temperature shall be controlled by monitoring the temperature and maintaining the temperature within Limiting 
Conditions for Operation (LCO) and the Safety Limit (SL).

3.2.1.1.1 Maintain DST Waste Temperature within Limiting Conditions for Operation and Safety Limit. The ventilation systems shall provide cooling to maintain the Waste Temperature in the DSTs to within the limiting conditions for operation (LCO) and the Safety Limit (SL).

3.2.1.1.1.1.1 Ventilating to Maintain Waste Temperatures below Limiting Conditions for Operation (LCO). The ventilation shall be removing heat to help maintain the waste temperature below the safety limit of $250 \mathrm{~F}$ at either of the following LCOs:

a. $<=195 \mathrm{~F}$ in all levels of the WASTE.

OR

b. $<=195 \mathrm{~F}$ in the top $15 \mathrm{ft}$ of the WASTE and $<=215 \mathrm{~F}$ in the WASTE below $15 \mathrm{ft}$.

3.2.1.1.2 Control DST Vapor Space Pressure. The vapor space pressure in DSTs shall be controlled to prevent overpressurization and underpressurization, to protect the tank against structural damage, prevent excessive hydrostatic loads on the tank structure and show that the ventilation is operating. The vapor space pressure shall be controlled by monitoring the vapor space pressure, comparing the vapor space pressure to authorization basis limits and maintaining vapor space pressure within limits.

3.2.1.1.1 Maintain DST Vapor Space Pressure within Limits. The ventilation system shall maintain the vapor space pressure in DSTs to within the limits.

3.2.1.1.2.1.1 Ventilate to Maintain DST Vapor Space Pressure to within Limits. The DST and AWF tank primary ventilation systems shall maintain vapor space pressures of all tanks $<0 \mathrm{kPa}$ ( $<0$ in. $w g$ ) relative to atmospheric pressure.

3.2.1.1.3 Control DST Gaseous Discharge. The DST gaseous effluent discharge shall be controlled to ensure that gases released to the atmosphere meet applicable laws and regulations for release of radionuclides, airborne particulates and hazardous/toxic chemicals. Gaseous discharge shall be controlled by monitoring gaseous discharge and maintaining the gaseous discharge within authorized limits.

3.2.1.1.3.1 Monitor DST Gaseous Effluent Discharge. The DST gaseous effluent discharge shall be monitored to obtain data that will be used to determine if limits are being exceeded. Monitoring shall include obtaining, transmitting, receiving, recording and displaying the gaseous effluent discharge data.

3.2.1.1.3.1.1 Record Sampling Systems for Ventilation Exhaust Stacks. Radioactive air emissions sampling systems shall be designed to meet the sampling and analysis methodology of 40 CFR 61 , Subpart H, Section 61.93 .

3.2.1.1.3.1.2 Design Requirements for Sample System and Stack Flow Rate Instruments. Sample system and stack flow rate instruments for regulated stacks (as listed in HNF-SD-WM-SAR-067, REV 0) shall be designed to meet the accuracy certification requirements of 40 CFR 52 Appendix $E$.

3.2.1.1.3.1.3 Operating the CAM during Exhaust System Operation. The CAM shall operate 
continuously while the exhaust systems are in operation, maintaining isokinetic sampling conditions. The CAM shall measure the radiation levels of the sampled flow stream and detect levels in excess of a preset level.

3.2.1.1.3.2 Maintain DST Gaseous Effluent Discharge within Authorized Limits. The ventilation system shall maintain DST gaseous effluent discharge to within limits.

3.2.1.1.3.2.1 Control of Toxic and Hazardous Substance. Releases to the atmosphere of toxic and hazardous substances shall be controlled to prevent exceeding the source impact levels established through the permitting process as defined in WAC 173-400 and WAC 173-460, and listed in the Hanford Site Air Operating Permit, HNF-AOP-97-1, and the permissible exposure levels (PELs) identified in Subpart Z of 29 CFR 1910.

3.2.1.3.2.2 HEPA Filter Particulate Removal Efficiency. HEPA filters shall have a nominal particulate removal efficiency of greater than or equal to $99.95 \%$. HEPA filters shall have the design air flow through the filter in accordance with: American Society of Mechanical Engineers (ASME) AG-1, Code of Nuclear Air and Gas Treatment.

3.2.1.3.2.3 HEPA Filter Description. HEPA filters shall be aerosol testable and replaceable.

3.2.1.1.3.2.4 CAM Interlock Shutdown during Excessive Radiation Levels. The CAM shall activate an interlock to shut down the exhauster upon detection of a radiation level that exceeds the preset level. Upon CAM failure, the monitors shall actuate an alarm and an interlock to shut down the ventilation exhaust system.

\subsection{DST Flammable Gas Concentration.}

\subsection{Maintain DST Flammable Gas Concentrations within Lower Flammability}

Limits. The ventilation shall maintain the flammable gas concentrations in DST to within Lower Flammability Limits.

3.2.1.1.4.1 Provide Sufficient Primary Tank Vapor Space Flow to Maintain Flammable Gas Concentration below Lower Flammability Limit. The ventilation system shall be capable of maintaining the Flammable Gas Concentration below $25 \%$ of the Lower Flammability Limit.

3.2.1.2 DCRT Waste Storage. The W-314 system shall accomplish DCRT Waste Storage as follows:

3.2.1.2.1 Control DCRT Temperature. The temperature of the waste in the DCRT shall be controlled to prevent excessive stresses to the primary tank, structural degradation of the concrete shell, and organic salt nitrate reactions. The temperature shall be controlled by monitoring the temperature and maintaining temperature within the Safety Limits (SL).

3.2.1.2.1 Maintain DCRT Waste Temperature within the Safety Limits. The ventilation system shall provide cooling to help maintain the Waste Temperature in the DCRT to within the Safety Limit (SL).

3.2.1.2.1.1.1 Ventilate to Maintain DCRT Waste Temperature within Safety Limit. The Ventilation shall be removing heat to help maintain the waste temperature below the safety limit of $250 \mathrm{~F}$. 
3.2.1.2.2 Control DCRT Vapor Space Pressure. Vapor space pressure in DCRTs shall be controlled to prevent overpressurization and underpressurization, protect the tank against structural damage, prevent excessive hydrostatic loads on the tank structure and show that the ventilation system is operating. The vapor space pressure shall be controlled by monitoring the vapor space pressure, comparing the vapor space pressure to limits and maintaining vapor space pressure within limits.

3.2.1.2.1 Maintain DCRT Vapor Space Pressure Within Limits. The ventilation system shall maintain the vapor space pressure in DCRT to within limits.

3.2.1.2. 2.1.1 Maintain Ventilation Vacuum in DCRT. The active ventilation system for all DCRT shall maintain a vacuum in the tank vapor space, relative to atmospheric pressure.

3.2.1.2.3 Control DCRT Gaseous Effluent. The gaseous effluent discharge in DCRT shall be controlled to ensure that gases released to the atmosphere meet applicable laws and regulations for release of radionuclides, airborne particulates and hazardous/toxic chemicals. Gaseous discharge shall be controlled by monitoring gaseous discharge and maintaining gaseous discharge within authorized limits.

3.2.1.2.3.1 Monitor DCRT Gaseous Effluent Discharge. The DCRT gaseous effluent discharge shall be monitored to obtain data that will be used to determine if limits are being exceeded. Monitoring shall include obtaining, transmitting, receiving, recording and displaying the gaseous effluent discharge data.

3.2.1.2.3.1.1 Record Sampling Systems for Ventilation Exhaust Stacks. Radioactive air emissions sampling systems shall be designed to meet the sampling and analysis methodology of 40 CFR 61 , Subpart H, Section 61.93.

3.2.1.2.3.1.2 Design Requirements for Sample System and Stack Flow Rate Instruments. Sample system and stack flow rate instruments for regulated stacks (as listed in HNF-SD-WM-SAR-067, REV 0) shall be designed to meet the accuracy certification requirements of 40 CFR 52 Appendix $E$.

3.2.1.2.3.1.3 Operating the CAM during Exhaust System Operation. The CAM shall operate continuously while the exhaust systems are in operation, maintaining isokinetic sampling conditions. The CAM shall measure the radiation levels of the sampled flow stream and detect levels in excess of a preset level.

3.2.1.2.3.2 Maintain DCRT Gaseous Effluent Discharge within Authorized Limits. The ventilation system shall maintain the DCRT gaseous effluent discharge to within limits.

3.2.1.2.3.2.1 Control of Toxic and Hazardous Substances. Releases to the atmosphere of toxic and hazardous substances shall be controlled to prevent exceeding the source impact levels established through the permitting process as defined in WAC 173-400 and WAC 173-460, and listed in the Hanford Site Air Operating Permit, HNF-AOP-97-1, and the permissible exposure levels (PELs) identified in Subpart $Z$ of 29 CFR 1910.

3.2.1.2.3.2 HEPA Filter Particulate Removal Efficiency. HEPA filters shall have a nominal particulate removal efficiency of greater than or equal to $99.95 \%$. HEPA filters shall have the 
design air flow through the filter in accordance with: American Society of Mechanical Engineers (ASME) AG-1, Code of Nuclear Air and Gas Treatment.

3.2.1.2.3.3 HEPA Filter Description. HEPA filters shall be aerosol testable and replaceable.

3.2.1.2.3.2.4 CAM Interlock Shutdown during Excessive Radiation Levels. The CAM shall activate an interlock to shut down the exhauster upon detection of a radiation level that exceeds the preset level. Upon CAM failure, the monitors shall actuate an alarm and an interlock to shut down the ventilation exhaust system.

\subsection{DCRT Flammable Gas Concentration.}

3.2.1.2.1 Maintain DCRT Flammable Gas Concentration within Limiting Condition for Operation. The ventilation system shall maintain the flammable gas concentration in DCRT to within the limiting conditions for operation.

3.2.1.2.1.1 Provide Sufficient Tank Vapor Space Flow to Maintain Flammable Gas Concentration below Lower Flammability Limit. The ventilation system shall be capable of maintaining the Flammable Gas Concentration below $25 \%$ of the Lower Flammability Limit.

3.2.1.3 Transfer Managed Tank Waste. The waste transfer system shall transfer supernatant and interstitial liquids which have not been pretreated from SSTs, DSTs, and active miscellaneous tanks to DSTs for storage as necessary to resolve safety concerns, manage tank space or provide feed for the Concentrate Waste function. Also included shall be the receipt and transfer of liquid wastes to DST storage from: (a) generators external to the Remediate Tank Waste function; and (b) the 242-A Evaporator. This function shall also include treatment/preparation of liquid, gaseous, and solid wastes generated as a result of the transfer of tank waste as necessary to meet criteria for release to the environment or acceptance criteria for receiving functions. Any conditioning performed under this function will be limited to the activities required to ensure the waste to be transferred meets the waste compatibility requirements allocated to the waste transfer system interfaces.

3.2.1.3.1 Confine Waste Along Transfer Route. The transfer system shall provide a primary boundary along a transfer route.

3.2.1.3.1 Confine Waste Within the Valve Manifolds and Jumpers. The transfer valve manifolds and jumpers shall provide the primary containment boundary for waste routed through the process pits.

3.2.1.3.1.1.1 Visible Leakage Test Boundaries. Pressure boundaries shall be designed for no visible leakage at test pressure in accordance with ASME B31.3.

\subsection{Confine Waste Leakage Along Transfer Route.}

3.2.1.3.1 Confine Waste Leakage Within the Transfer-Associated Structures. The Transfer Valving System shall confine waste leaks occurring within the transfer-associated structures. Valve pits, pump pits, clean out boxes (COBs), and diversion boxes shall be provided with a drain path to a DST or Double-Contained Receiver Tank (DCRT). Cover blocks shall be provided for all transfer-associated structures that are physically connected to an active waste transfer route. 
3.2.1.3.2.1.1 Leak Detection Systems for Transfer-Associated Structures. Each transfer-associated structure shall be provided with a leak-detection system that is designed and operated so that it will detect the failure of either the primary or secondary containment structure or the presence of any release of dangerous waste or accumulated liquid in the secondary containment system within twenty-four hours, or at the earliest practicable time if the owner or operator can demonstrate that existing detection technologies or site conditions will not allow detection of a release within twenty-four hours.

3.2.1.3.2. 2 Process Pit and Cover Block Material Compatibility. New process pits and cover blocks shall be constructed of or lined with materials that are compatible with the waste(s) to be placed in the tank system and must have sufficient strength and thickness to prevent failure owing to pressure gradients (including static head and external hydrological forces), physical contact with the waste to which it is exposed, climactic conditions, and the stress of daily operations.

3.2.1.3.2.1.3 Eliminate Direct Spray Leakage Paths. The cover assembly for a waste transfer-associated structure that is physically connected to the transfer route shall confine direct spray leaks to the inside of the structure. Transfer system covers shall be designed to eliminate direct spray leakage paths. Transfer system cover assemblies shall fit their supporting structure so that there are no paths for a direct spray leak of tank waste to the atmosphere. When transfer system cover penetrations are not in use, they shall be plugged.

3.2.1.3.2.1.4 Confine Direct Spray Leaks Above Grade. The abovegrade portions of process pits, diversion boxes, valve pits, and COBs shall confine direct spray leaks to the inside of the structure and shall be designed to eliminate direct spray leakage paths. Transfer system cover assemblies shall fit their supporting structure so that there are no paths for a direct spray leak of tank waste to the atmosphere. Abovegrade portions of process pits, diversion boxes, valve pits, and COBs shall be designed to provide an intact boundary to confine waste leakage within the waste transfer-associated structure until it is completely filled with leaked waste. Unsealed openings in the abovegrade portions of process pits, diversion boxes, and valve pits shall be plugged, and holes in $\mathrm{COB}$ covers from previous repairs or uncompleted modifications shall be sealed to prevent premature waste outleakage and the formations of a surface pool of waste.

3.2.1.3.2.2 Contain Leakage Within Transfer Piping Encasement. The Transfer Piping System shall contain leakage from the primary piping and route the leaked waste to a transfer-associated structure.

3.2.1.3.2.2.1 Pipe Encasement Capacity. Pipe encasements shall be able to contain the entire volume of the waste in any failed section of the primary line.

3.2.1.3.2.2 Encasement Piping Extension. The encasement piping shall extend through the concrete wall of the pits to maintain secondary containment.

3.2.1.3.2.2.3 Channel Waste from Primary Pipe. Transfer pipe encasement shall channel waste leaked from a primary pipe to a transfer-associated structure where the leak can be detected.

3.2.1.3.2.2.4 Encasement Pipe Design Pressure. The design pressure of the encasement pipe shall be determined based upon the maximum pressure that could occur assuming a 
guillotine break of the primary pipe. Determination of encasement design pressure shall take into consideration the pump head flow characteristic, pressure drop across the primary pipe supports located within the encasement annular space, changes in elevation of the line, and the worst case location of a primary pipe break.

3.2.1.3.2.3 Detect Leak in Transfer Associated Structures. Transfer associated structures shall be provided with the capability to detect a liquid leak within the structure.

3.2.1.3.2.3.1 Leak Detector Capability. A leak detector shall be capable of detecting a 2.54-cm-(1-in)-deep liquid accumulation.

3.2.1.3.2.3.2 Leak Detection System Operation. The leak detection system shall activate an alarm or an interlock to prevent or stop the operation of the transfer pump when a leak is detected.

\subsubsection{Physical.}

3.2.2.1 Dome Loading. The static dome loading shall not exceed the equivalent maximum depth of soil above the tanks, measured at the center (crown) of the tank dome and the live load shall not exceed the maximum value as described in Table 3-8 (attached) in order to prevent structural damage to tank domes.

TABLE 3-8 Authorized Dome Loads

\begin{tabular}{|c|c|c|}
\hline \multirow{2}{*}{ Tank Type } & \multicolumn{2}{|c|}{ Additional Allowable Loads Above Baseline } \\
\cline { 2 - 3 } & Soil (ft) & Concentrated (ton) $^{\star}$ \\
\hline SST (100 Series - 75 ft dia.) & None & 100 \\
\hline SST (200 Series - 20 ft dia.) & None & 50 \\
\hline DST (SY, AW, AN, AP) & $7.5^{\star \star}$ & 100 \\
\hline DST (AWF Tanks - AY, AZ) & $8.3^{\star \star}$ & 100 \\
\hline DCRT & N/A & None $^{\star \star \star}$ \\
\hline Catch Tanks & None & None $^{\star \star \star}$ \\
\hline MISFs & None & None $^{\star \star \star}$ \\
\hline
\end{tabular}

* Baseline corresponds to existing field conditions of average soil height and total existing load above tank.

** Baseline comparison is irrelevant. These numbers represent total allowable soil height as measured from apex to top of tank.

*** Does not include restriction of personnel or equipment carried by personnel.

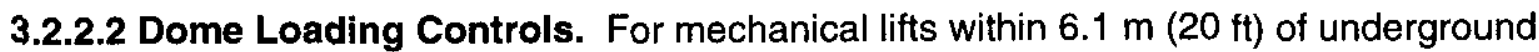
storage tank, the lower equipment boundary of the lifted item (e.g., bottom of the cover block,

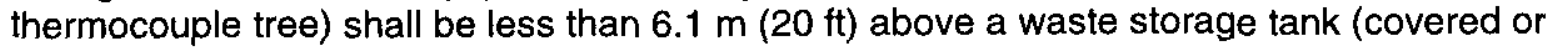


HNF-SD-W314-DRD-001, Rev. 2

uncovered). Mechanical lifts travelling over a MISF are not allowed.

This control is applicable for SSTs (100 series), DSTs, and AWF tanks.

3.2.3 Reliability, Maintainability, and Availability.

3.2.3.1 Design Life. Each system shall have a design life of at least 35 years.

\subsubsection{Maintenance.}

3.2.3.2.1 Maintenance. Each design shall provide for routine maintenance, repair, or replacement of equipment subject to failure. Safety class items shall be designed to allow inspection, maintenance, and testing to ensure their continued functioning, readiness for operation, and accuracy. Ancillary equipment, such as pumps, blowers, motors, compressors, gear trains, and controls, shall be located in an area least likely to be contaminated. The design of equipment that must be located within confinement systems shall allow for in-place maintenance or replacement. The capability shall be provided for the maintenance of contaminated equipment that cannot be repaired in place. This capability shall include the necessary provisions for confinement, ventilation, and waste control.

3.2.3.2 Testing. Designs shall include provisions for periodic testing monitoring, surveillance, and alarm systems. In addition, designs shall allow for periodic testing, under simulated emergency conditions, of safety class items that are required to function under emergency conditions. All systems designed to comply with DOE 6430.1A, Section 1300-1.4.2, shall be testable in-place. Designs shall allow for routine in-place testing of high efficiency particulate air (HEPA) filtration systems as outlined by ASME N510 and ASME AG-1b-1993. In the event of a conflict, AG-1 shall take precedence.

3.2.3.2.3 Maintainability. The design of equipment shall incorporate the objective of efficient maintainability. The surveillance, testing, and maintenance of a system and its restoration to operational effectiveness shall be achieved at minimum life-cycle cost with a minimum level of support services. UCRL 15673 shall be considered for system design.

3.2.3.2.4 Non-Interruption of Operation. The maintenance and testing of Safety Class electrical equipment shall be capable of being performed without interrupting the operation of the tank farm.

3.2.3.3 Fault Detection/Fault Isolation. Designs shall provide for the detection and isolation of faults to systems, structures, and components as necessary in order to minimize the risks associated with faulty operation to plant, personnel and environment. Protection systems and associated instrumentation and controls shall be designed in accordance with DOE 6430.1A, Section 1660-99.0.2.

3.2.3.4 Calibration. Systems shall be designed to allow periodic calibration in accordance with HNF-PRO-456 section 2.8.2 or manufacturer's instruction.

\subsubsection{Environmental Conditions.}

Each system shall meet the requirements of Section 3.2.1 during exposure to the following natural and induced environments. 
3.2.4.1 Natural Environments. Available meteorological data shall be considered to identify conditions that may influence the design and operation of the facility. Meteorological data to be considered shall include expected annual ranges and distribution of the following variables:

o Wind direction and speed

o Atmospheric stability

o Temperature

o Atmospheric water vapor

o Mean joint temperature and specific humidity

As a minimum, at least one year of meteorological data shall be used to properly develop estimated joint frequency distributions of wind speed and stability conditions. These data shall be used to estimate the dispersal of effluents under normal and accident conditions.

3.2.4.1.1 Temperature. Each system shall operate within the ambient air temperature range of 48.9 degrees $C$ ( 120 degrees $F)$ to -35.5 degrees $C$ ( -32 degrees $F)$, and with a maximum 24 hour differential of 28.9 degrees $\mathrm{C}$ (52 degrees $\mathrm{F}$ ).

Each subsurface system shall operate within the following minimum soil temperatures below ground surface:

$1.3 \mathrm{~cm} .(0.5 \mathrm{in}):. \quad-19.5$ degrees $\mathrm{C}(-3.0$ degrees $\mathrm{F})$

$38 \mathrm{~cm}$. (15 in.): $\quad-8.8$ degrees $C(16.1$ degrees $F)$

$92 \mathrm{~cm}$. (36 in.): $\quad 0.8$ degrees $\mathrm{C}$ (33.5 degrees $\mathrm{F}$ )

3.2.4.1.2 Relative Humidity. RPP systems shall be designed to operate in humidity ranges between $0 \%$ and $100 \%$. Rate of change is negligible.

3.2.4.1.3 Surface Precipitation. The RPP systems shall withstand the loads and conditions for surface precipitation identified in HNF-PRO-097.

3.2.4.1.4 Sand and Dust. Design of systems shall consider potential sand/dust concentrations of $0.177 \mathrm{gm} /$ cubic meter with a typical size of 350 micrometers.

3.2.4.1.5 Natural Loads. Each system shall be designed to withstand the wind, earthquake, roof, flood, soil, ashfall and combination loads specified in HNF-PRO-097.

3.2.4.1.5.1 Wind Loading. RPP structures, systems, equipment, and components shall withstand the loads and conditions for wind loads as identified in HNF-PRO-097.

3.2.4.1.5.2 Earthquake Loads. Earthquake load design for buildings and other structures shall be determined in accordance with HNF-PRO-097.

3.2.4.1.5.3 Ashfall Loads. The RPP structures, systems, equipment and components shall withstand the loads and conditions for ashfall as identified in HNF-PRO-097. 
3.2.4.1.6 Solar Radiation. The 200E/W tank farm system shall be designed to operate in a solar radiation range between 4 and 406 Watts per square meter.

3.2.4.1.7 Lightning. A risk analysis due to lightning in accordance with NFPA 780-92 shall be conducted when designing a new facility. Lightning protection systems shall be designed in compliance with NFPA 780-92.

\subsubsection{Induced Environments.}

3.2.4.2.1 Radiation and Chemical. Equipment installed in the tanks shall be capable of performing their intended function for the duration of their intended useful life with no adverse affects due to the radiological and chemical environment in the tanks. This environment, for DSTs, is described in HNF-2937.

3.2.4.2.2 Vibration. Equipment supports shall be designed to avoid resonance resulting from the harmony between the natural frequency of the structure and the operating frequency of reciprocating or rotating equipment supported on the structure. The operating frequency of supported equipment shall be determined from manufacturers data prior to completion of structural design. Resonance shall be prevented by designing equipment isolation supports to reduce the dynamic transmission of the applied load.

\subsubsection{Flexibility and Expansion.}

Each system design shall, to the maximum extent practicable, provide sufficient flexibility to accommodate for programmatic changes or operations modifications.

3.2.5.1 Waste Transfer System Flexibility. To satisfy the flexibility and contingency action requirements of DOE $6430.1 \mathrm{~A}$ and DOE 5820.2A, the waste transfer system shall be flexible to the extent that liquid waste transfers between any:

a. tank farm; or

b. DSTs within a farm

are possible during an emergency situation (e.g. a leak), or to accommodate programmatic changes or operational modifications. Interconnected tank farms with adequate transfer capabilities and spare capacity may be considered as a single tank farm for the purposes of this requirement.

\subsection{Design and Construction.}

Design and construction shall be in compliance with DOE 6430.1A, ASME B31.3, and 40 CFR 264.

\subsubsection{Materials, Processes, and Design Practices.}

3.3.1.1 Corrosion Prevention and Control. Underground storage tanks, associated underground piping, underground ancillary equipment (e.g., piping, fittings, flanges, valves, and pumps used to distribute, meter, or control the flow of regulated substances to or from any underground storage tank) shall be designed to have cathodic protection, be constructed of non-corrodible material, steel clad with a non-corrodible material, or designed in a manner to prevent the release or threatened release of any stored substance as a result of corrosion. 
3.3.1.1.1 Cathodic System Protection. If active cathodic corrosion protection systems are used, engineered features that protect against abnormal conditions such as stray currents or system failure shall be provided.

3.3.1.1.2 Cathodic System Calibration. Active cathodic corrosion protection systems shall allow for calibration and inspections and/or testing for all sources of impressed current.

\subsubsection{Secondary Containment Monitors.}

3.3.1.2.1 Hazardous Release Detection. The system shall be provided with a leak-detection system that is designed and operated so that it will detect the failure of either the primary or secondary containment structure or the presence of any release of dangerous waste or accumulated liquid in the secondary containment system within twenty-four hours, or at the earliest practicable time if the owner or operator can demonstrate that existing detection technologies or site conditions will not allow detection of a release within twenty-four hours.

3.3.1.2.2 Accumulated Liquid Detection. The system shall be capable of detecting accumulated liquids in secondary containment systems.

\subsubsection{Solids Monitoring.}

3.3.1.3.1 Monitoring/Sampling. Monitoring and sampling shall be in accordance with DOE 5400.1 and DOE 5400.5.

\subsubsection{Controls.}

3.3.1.4.1 Spill Prevention Controls. The system shall provide controls to prevent spills, leaks, and overflows for all tank or containment systems (e.g. check valves, dry disconnect couplings, level sensing devices, liquid level alarms, and maintenance of sufficient freeboard.)

3.3.1.4.2 Collection of Releases. The system secondary containment systems shall collect releases of hazardous waste or accumulated liquids until the collected material is removed.

3.3.1.4.3 Waste Transfer Equipment Manual Restart. The waste transfer equipment shall require manual action for restart following loss and subsequent recovery of operating electrical power.

3.3.1.5 Ancillary Equipment Support/Protection. The ancillary equipment shall be supported and protected against physical damage and excessive stress due to settlement, vibration, expansion, or contraction.

3.3.1.6 Power Systems. The electrical power systems shall be in accordance with DOE 6430.1A Division 16, NFPA 70 and ANSI C2 for primary power.

3.3.1.7 Other Electrical. The electrical system shall be in accordance with DOE $6430.1 \mathrm{~A}$ Division 16, NFPA 70, and ANSI C2.

\subsubsection{Secondary Containment.}

3.3.1.8.1 Replacement or New Construction. For system replacement or new construction 
of high-level waste handling, transfer, and storage facilities (e.g., tanks, bins, pipelines, and capsules) the system shall provide double contained facilities.

3.3.1.8.2 Ancillary Equipment. The system ancillary equipment shall provide secondary containment, where ancillary equipment is any device including, but not limited to, such devices as piping, fittings, flanges, valves, and pumps, that are used to distribute, meter, or control the flow of dangerous waste from its point of generation to a storage or treatment tank(s), between dangerous waste storage and treatment tanks to a point of disposal on-site, or to a point of shipment for disposal off-site.

3.3.1.8.3 Materials. The system secondary containment materials shall be compatible with waste(s).

3.3.1.8.4 Structure. The system secondary containment structure shall have sufficient strength and thickness to prevent failure owing to the following occurrences:

a. pressure gradients (including static head and external hydrological forces

b. physical contact with waste to which it is exposed

c. stress of daily operations (including stresses from vehicular traffic)

3.3.1.8.5 Placement. The system secondary structure shall be sloped or otherwise designed to drain and remove liquids resulting from leaks, spills, or precipitation.

3.3.1.8.6 Transfer of Leaked Liquids. The system secondary containment systems shall be equipped with transfer capability to retrieve any liquids leaked from the primary system.

\subsubsection{Radiological and Hazardous Material Protection.}

3.3.1.9.1 Optimization Methods. During the design of new facilities or modification of old facilities, the following objectives shall be adopted:

(a) Optimization methods shall be used to assure that occupational exposure is maintained ALARA in developing and justifying facility design and physical controls.

3.3.1.9.2 Sampling/Monitoring. The design of new facilities or the modification of existing facilities that store, handle, or process radioactive materials shall allow for air and liquid effluent sampling and monitoring in accordance with WHC-SD-GN-DGS-30011, Section 9.1 through 9.4

3.3.1.9.3 Liquid Radioactive Waste Systems. Liquid radioactive waste systems shall be designed in accordance with WHC-SD-GN-DGS-30011, Section 10.4 through 10.7.

3.3.1.10 Pump, Valve, Sample Connections. Pumps, valves, and sample connections shall be in accordance with design related requirements in 40 CFR 265.

3.3.1.11 Underground Piping. If underground piping is included in the design, it shall be provided with secondary containment that is designed to prevent any migration of wastes or accumulated liquid out of the system to the soil, ground water, or surface water as specified in WAC 173-303-640. Piping design shall comply with WHC-SD-GN-DGS-30008. 
HNF-SD-W314-DRD-001, Rev. 2

3.3.1.12 Backfill Material. New tank systems or components that are placed underground and that are backfilled shall contain a backfill material that is non-corrosive, porous, and a homogeneous substance.

3.3.1.12.1 Backfill Installation. New tank systems or components that are placed underground and that are backfilled must be provided with a backfill material that is a noncorrosive, porous, homogeneous substance and that is installed so that the backfill is placed completely around the tank and compacted to ensure that the tank and piping are fully and uniformly supported. In addition, the backfill material shall provide resistance to pressure gradients above and below the system, and prevent failure due to settlement, compression, or uplift.

3.3.1.13 Lockout Devices. Each system shall be designed to accept lockout devices on all equipment determined to be capable of unexpectedly releasing hazardous energy or materials.

3.3.1.14 Restricted Materials. Designs for maintenance, repair, and demolition of DOE facilities shall comply with 29 CFR 1910 for control of asbestos-containing materials. If use, storage, or disposal of polychlorinated biphenyls (PCBs) or materials containing PCBs is to be encountered in a facility, the facility design shall comply with 40 CFR 761.

3.3.1.15 Ventilation System Materials. The ventilation system shall be designed using the material specified in ASME AG-1b-1997.

\subsubsection{Environmental Protection.}

\subsubsection{System Dose Equivalent.}

3.3.2.1.1 Radiological. Each system, when combined with all other Hanford operations, shall be designed to limit the combined annual dose equivalent to any member of the public in the general environment resulting from discharges of radioactive material to not exceed 25 millirems to the whole body, 75 millirems to the thyroid, and 25 millirems to any other critical organ.

3.3.2.1.2 Hazardous Material. The confinement of hazardous materials produced, processed, or stored shall be designed to minimize dose to a maximally exposed member of the public.

\subsubsection{Airborne Emissions.}

3.3.2.2.1 Radiological. Each system, when combined with all other Hanford operations, shall control the emissions of radionuclides to the air which exceed those amounts that would cause any member of the public to receive in any year an effective dose equivalent of 10 $\mathrm{mrem} /$ year.

3.3.2.2.1.1 Radionuclide Emissions. The limits on radionuclide emissions from tank farm operations shall be within the limits established in WAC 246-247 and HNF-PRO-450.

3.3.2.2.2 Hazardous Material, Each system when combined with all other Hanford operations, shall control the level of emissions of hazardous material to the air in accordance 
with WAC 173-460.

3.3.2.2.1 Toxic Air Pollutants. The limits on Toxic Air Pollutants (TAP) emitted to the environment from tank farm operations shall be within the limits established in WAC 173-460-050 (3) and WAC 173-460-080.

3.3.2.3 Ventilation/Filtration Systems. Ventilation and filtration systems shall be designed in accordance with ASME N509 and ASME AG-1b-1997. In the event of a conflict, AG-1 shall take precedence.

3.3.2.4 Ventilation Airborne Releases. Ventilation systems shall mitigate airborne release of radionuclides to maintain compliance with $40 \mathrm{CFR} 61$, subpart $\mathrm{H}$, page $11.1 \mathrm{~b}$.

3.3.2.5 Point Source Emission Rates. Radionuclide emission rates from point sources shall be measured in accordance with 40 CFR 61 or other procedures for which EPA has granted prior approval. Emissions measurements shall be made at all release points that have potential to discharge radionuclides into the air in quantities which could cause an EDE in excess of 1 percent of the standard. All radionuclides which could contribute greater than 10 percent of the potential EDE for a release point shall be measured.

3.3.2.6 Water Discharge. Disposal of water used, generated or processed by the system shall be in accordance with HNF-PRO-456, WAC 173-200-040, WAC 173-216 permits, and WAC 173-303-645(5). In the event of a conflict, the more restrictive requirement shall apply.

3.3.2.7 Liquid Effluent Discharge. Disposal of liquid effluents generated, used or processed by the system shall be in accordance with HNF-PRO-456. The liquid effluents shall not cause private or public drinking water systems downstream of the discharge to exceed the radiological limits in 40 CFR 141. Any liquid impacting drinking water shall have radionuclide concentrations below the maximum concentration levels (MCLs) given in WAC 246-290-310. In the event of conflict between regulating documents (CFR, WAC, DOE, or HNF), the more restrictive shall apply.

3.3.2.8 Oil-Filled Equipment. Oil-filled transformers installed near buildings shall comply with FM 5-4/14-8. Electrical equipment cooling material shall be handled in accordance with $29 \mathrm{CFR}$ 1910.120.

\subsubsection{Interchangeability.}

The system shall standardize the components used in the design to the maximum extent practicable.

\subsubsection{Safety.}

\subsubsection{Personnel Safety.}

3.3.4.1.1 General. Each system shall ensure that operating occupied areas do not exceed the airborne concentration limits for radiological emissions of HSRCM-1 for standard operating conditions. The design shall ensure that respirators are not required to meet the dose limits for standard operations. Engineered controls and features shall also be provided to minimize potential inhalation of radioactive and other hazardous materials under all conditions. 
3.3.4.1.2 Continuous Air Monitors. The system shall provide Continuous Air Monitors (CAM) which have high concentration alarms in the workplace and at effluent release points (i.e., ventilation exhaust stacks) to warn of increasing concentrations of airborne radioactive material.

3.3.4.1.3 Occupational Exposure Limits. The design objectives for exposure to a radiological worker shall be as low as is reasonable achievable (ALARA), but shall not exceed:

- A total effective dose equivalent (TEDE) of 5 rems (per year).

- The sum of the deep dose equivalent for external exposures and the committed dose equivalent to any organ or tissue other than the lens of the eye of 50 rems (per year).

- A lens of the eye dose equivalent of 15 rems (per year).

3.3.4.1.4 Air Monitoring Systems. Air monitoring systems shall comply with ANSI N13.1.

3.3.4.1.5 Air Monitors Calibration. The system air monitors shall provide for routine calibration and maintenance.

3.3.4.1.6 Air Monitor. The system air monitors shall measure one derived air concentration (DAC) when averaged over 8 hours (8 DAC-hours).

3.3.4.1.7 Central Radiation Monitoring and Alarm Readout. In addition to a local station alarm, radiation monitoring systems (criticality alarms, CAMs, alarms associated with stack monitoring systems) the system shall have central (i.e., control room or radiation monitoring office) readout and alarm panels that are accessible after a design basis accident (DBA) to evaluate internal conditions.

3.3.4.1.8 Controls to Limit Airborne Radioactivity. Processes and activities with the potential for producing airborne radioactivity shall include engineering controls to limit releases.

\subsection{Preliminary Shielding Design Criteria.}

3.3.4.1.9.1 Controlling Personnel Exposure. The design objective for controlling personnel exposure from external sources of radiation in areas of continuous occupational occupancy (2000 hours per year) shall be to maintain exposure levels below an average of 0.5 mrem (5 microsieverts) per hour and as far below this average as is reasonably achievable. The design objectives for exposure rates for potential exposure to a radiological worker where occupancy differs from the above shall be ALARA and shall not exceed 20 percent of the applicable standards in 835.202 .

3.3.4.1.9.2 Shield Design Criteria Table. Initial design effort should be directed to the lower radiation level of Table 3-9 for each zone category. Even lower levels should be sought if they can be achieved within the principle of ALARA. 
HNF-SD-W314-DRD-001, Rev. 2

TABLE 3-9 Shield Design Criteria

\begin{tabular}{|c|c|c|}
\hline $\begin{array}{c}\text { Zone } \\
\text { Category }\end{array}$ & Access Time Allowed & $\begin{array}{c}\text { Maximum } \\
\text { (microSv per hour) }\end{array}$ \\
\hline $\begin{array}{c}\text { Uncontrolled } \\
\text { Area }\end{array}$ & Full Time & 0.5 \\
\hline $\begin{array}{c}\text { Controlled } \\
\text { Area: }\end{array}$ & Full Time & 2.5 \\
\hline 1 & Less than 1 hour per day & 20 \\
\hline 2 & Less than 1 hour per week & 100 \\
\hline 3 & Less than 10 hours per year & 500 \\
\hline 4 & No normal access permitted & greater than 500 \\
\hline 5 &
\end{tabular}

Note: For design purposes the dose due to neutrons should be calculated by doubling the neutron quality factors (10 CFR 835).

\subsubsection{System Safety.}

3.3.4.2.1 Safety Items (Structures, Systems and Components). Safety Class items shall be designed to prevent or mitigate releases to the public that would otherwise exceed the offsite radiological risk guidelines or prevent a nuclear criticality. Those SSCs that support the safety function of a Safety Class SSC or also Safety Class SSCs.

Safety Significant items shall be designed to prevent or mitigate releases of radiological materials to onsite workers and toxic chemicals to the offsite public and onsite workers. Safety Significant SSCs also include those safety SSCs that protect the facility worker from serious injury (or fatality) because of hazards not controlled by institutional safety programs. Those SSCs that support the safety function of a Safety Significant SSC are also Safety Significant SSCs.

General Service items shall be designed to ensure occupant and worker safety via control by building codes and ISP (Institutional Safety Program (ISP) protecting against standard industrial hazards per DOE-STD-3009).

The following designations apply:

a. Safety Class

- DCRT Ventilation Systems

- DST and AWF Tank Ventilation Systems

- Waste Transfer Pipe Encasements

- Primary Tank Leak Detection System

- Transfer Leak Detection System

- Transfer System Covers

- Above Ground Portions of Process Pits, Diversion Boxes, Valve Pits and Clean Out Boxes

- SSC Support - Tank Farm Electrical Distribution 
b. Safety Significant

- HEPA Filter Units

- Service Water Flow Totalizers

c. General Services

SSCs not listed as Safety Class or Safety Significant are designated as General Services.

3.3.4.2.1.1 Engineering Evaluation for Safety Class and Safety Significant Systems. An engineering evaluation will be performed for safety class and safety significant systems installed by the W314 Project. The evaluation will examine the W314 systems credited in the Authorization Basis for accident prevention or mitigation. The systems will be evaluated against DOE Order 6430.1A "General Design Criteria", Section 1300-3 which establishes Safety Class Criteria for systems performing Safety Class functions. Section 1300-3 identifies criteria to be used, as applicable, in the design of Safety Class components and systems to ensure the system or component can perform its intended safety function. The criteria include quality assurance, single-failure and redundancy criterion, environmental considerations, maintenance and testing. The evaluation will evaluate each system against the criteria in section 1300-3, but will not evaluate the systems against all codes and standards. The evaluation will document how safety class and safety significant systems satisfy the safety class requirements of DOE $6430.1 \mathrm{~A}$ and the safety functions of the Authorization Basis. The evaluation may include consideration of human/equipment reliability, repair/response time, failure modes and effects, fail safe modes of operation, and TSR operational controls. Examples of this include:

a. For the Master Pump Shutdown System, an automatic system having evaluated safety functions may be utilized in lieu of 30-minute manual operator action by demonstrating equivalent safety system reliability.

b. For the new safety class primary tank exhausters, allowance may be taken for repair of failed components within the outage times prescribed in the $\mathrm{BIO}$, considering flammable gas and thermal build-up.

The engineering evaluation will provide the basis for identification of equipment critical characteristics, commercial grade item dedication, Safety Equipment List information, spare parts requirements, and operations and maintenance procedures. Acceptance testing (ATPs) and operational testing (OTPs) may be utilized to demonstrate that applicable equipment safety functions and requirements are met.

3.3.4.2.2 Flammable Gas. When there is a reasonable possibility of flammable atmospheres being present, material handling equipment and hand tools shall be of the type to prevent sources of ignition. Any electrical equipment or instrument installed in a tank, both in the waste and in the dome space, or in a pump or valve pit, must meet the flammability requirements for those spaces as specified in the authorization basis.

\subsubsection{Human Engineering.}

3.3.5.1 Human Dimension Consideration. Equipment that is to be used by personnel shall be designed or selected to accommodate their body dimensions. This equipment shall include control panels, work tables and counters, enclosures, seating, storage, special clothing, and any other equipment designed for an operator. The design of equipment for personnel shall accommodate a wide variety of body dimensions. Generally, it is recommended that equipment 
dimensions accommodate the fifth to ninety-fifth percentile of the user population. For recommended data representing these percentiles, see NUREG 0700, Section 6.1, and MIL-STD-1472, Section 5.6.

3.3.5.2 Lighting. Adequate light levels are necessary to ensure optimum performance in all work areas. Glare and shadowing shall be avoided. For recommended control room illumination levels, luminance ratios, reflector levels and further lighting considerations, see NUREG 0700, Section 6.1. Lighting designs shall consider environmental degradation effects to ensure adequate lighting intensities can be provided on a long-term basis.

3.3.5.3 Noise. RPP systems, components, and equipment shall be designed to:

-Minimize noise levels where practical and ensure that the limits of DOE 5480.10 are not exceeded

-Ensure that verbal communications are not impaired

-Ensure that auditory signals are readily detectable

-Minimize auditory distraction and irritation that can cause operator fatigue

3.3.5.4 Component Arrangement. Component arrangements shall be in accordance with EPRI NP-3659, Chapter 4 and NUREG 0700, Section 6.8 and 6.9.

3.3.5.5 Display Devices. Displays shall be in accordance with NUREG 0700, Section 6.5, MIL-STD-1472, Section 5.2, and NUREG CR-2496.

3.3.5.6 System Controls. Control panels shall be organized in accordance with EPRI NP 3659, Chapter 4 and NUREG 0700, Section 6.1, 6.3, 6.7, and 6.9.

3.3.5.7 Component Controls. Each control device shall be in accordance with NUREG 0700, Section 6.4 and MIL-STD-1472, Section 5.4.

3.3.5.8 Warning and Annunciator Systems. In addition to alarming at the computer monitoring and control system, any condition or situation that presents a safety threat to personnel must have a local alarm that is able to be heard and seen by anyone in the area that could be affected by the condition/situation. Warning systems shall be in accordance with MIL-STD-1472, Section 5.3, NUREG 0700, Section 6.3., and NUREG 0700, Section 6.2.

3.3.5.9 Communication Systems. Communication systems shall be designed in accordance with MIL-STD-1472 and NUREG 0700, Section 6.2.

3.3.5.10 Labels. New equipment and/or modifications to existing equipment shall be labeled in standardized format in accordance with the tank form labeling program as specified in HNF-IP-0842, Volume II, Section 6.1, Rev. 0.

\subsubsection{System Security.}

Reserved

\subsection{Documentation.}

Records, documents, and document control pertinent to design functions shall be in accordance with HNF-PRO-210, HNF-PRO-211, HNF-PRO-222, HNF-PRO-224, HNF-PRO-229,

HNF-PRO-231, HNF-PRO-232, and HNF-PRO-233. Drafting Standards for drawings shall be in 
accordance with HNF-PRO-709.

\subsection{Logistics.}

\subsubsection{Maintenance and Operation.}

Remote, limited, or contact maintenance and operation shall be in accordance with the following threshold values.

3.5.1.1 Fully Remote Maintenance and Operation. Each system or portion of a system having radiation levels greater than $50 \mathrm{mrem} / \mathrm{hr}$ contact exposure shall be designed to be remotely maintained and operated or designed to require no maintenance and be remotely operated.

3.5.1.2 Limited Contact Maintenance and Operation. Each system or portion of a system having radiation levels greater than $0.10 \mathrm{mrem} / \mathrm{hr}$ to less than or equal to $50 \mathrm{mrem} / \mathrm{hr}$ shall be designed for limited contact maintenance and operation. Designs shall consider remote removal of radiation sources and decontamination prior to personnel entry.

3.5.1.3 Full Contact Maintenance and Operation. Each system or portion of a system having radiation levels less than or equal to $0.10 \mathrm{mrem} / \mathrm{hr}$ shall be designed for full contact maintenance and operation.

\subsubsection{Waste Handling, Storage, and Disposal.}

Solid waste handling, storage and disposal shall be performed in accordance with WHC-SD-GN-DGS-30011, Section 10.1 through 10.3.

\subsubsection{Asbestos-Containing Materials.}

The system shall comply with 29 CFR 1910 during maintenance, repair, and demolition of DOE facilities.

\subsubsection{Polychlorinated Biphenyls (PCBs).}

The system design shall comply with 40 CFR 761 with regards to the use, storage, or disposal of Polychlorinated Biphenyls (PCBs) or materials containing PCBs.

\subsubsection{Supply/Support.}

The system design shall, to the greatest extent practicable, use readily available parts and components.

\subsubsection{Transportation Hazardous Materials.}

Any system or component used to ship hazardous materials shall be designed to meet the requirements of HNF-PRO-154, 156 to 158,163 , and 166.

\subsection{Personnel and Training.}

\subsubsection{Personnel.}

The W-314 system shall be operated by personnel possessing qualifications in accordance with DOE 5480.20A Chapter IV. 


\subsubsection{Training.}

The W-314 system operations personnel shall be trained in accordance with DOE 5480.20A Chapter I.

\subsection{Characteristics of Specific Elements.}

Characteristics of the specific elements of the $W-314$ system elements (see section 3.1.1.1) are identified in the following subsections. The Upgrade Scope Summary Report (USSR) was used as the basis for the inclusion of "requirements" within this section.

\subsubsection{Primary Ventilation Train Filter Instrumentation.}

The primary ventilation system instrumentation for the AN, AP, and AW Tank Farms and DCRT 244-S shall provide monitors of pre-filter and HEPA filter differential pressures, exhaust temperatures, and exhaust heater differential pressures.

\subsubsection{Waste Transfer Leak Detection.}

The waste transfer instrumentation system shall detect waste leaks in the transfer system, primary pipelines in DST Tank Farms, DCRT 244-S, and all new piping.

\subsubsection{Waste Transfer Routing Verification.}

The waste transfer instrumentation system shall provide waste transfer routing verification on routing between DST Tank Farms and DCRT 244-S.

\subsubsection{Master Pump Shutdown System.}

The waste transfer control system shall provide a master pump shutdown system for the DST and SST Tank Farms.

\subsubsection{Annunciated Signals and Alarm Displays.}

The signal routing and display system shall provide a centralized monitoring system for signals annunciated in the DST farms (by "Panalarm") and shall provide alarm displays in the DST farms to replace the existing "Game-Well" system.

\subsubsection{TMACS Alarm Signal Routing.}

The system shall provide alarm signal inputs to the TMACS from the A, BY, C, SX, and U Tank Farms and CR-271, 242-T, 244-AR, and 204-AR.

\subsubsection{Pit/Diversion Box Protective Coating}

The protective coating for selected pits shall be assessed and repaired as necessary in order to meet all decontaminability and/or regulatory compliance criteria.

\subsubsection{Manifold Jumper/Valve Operating System}

The jumper arrangements in selected valve and pump pits (Valve pits AN-A, AN-B, AW-A, AW-B, AP, AN-01A, AZ-01A/02A [flexible]; pump pits AZ [new pit]) shall be developed to provide a greater degree of flexibility in transfer routes, reduce jumper changeout and maintenance requirements, and minimize personnel exposure.

\subsubsection{Waste Transfer Pipe Lines.}

Waste transfer pipe lines shall be installed between the following facilities:

- extending SLL-3160 to AN-104

- extending SNL-3150 to AN-01A 
- pump pit $A N-01 A$ to new $A Z$ valve pit - pump pit AZ-01A to new $A Z$ valve pit - pump pit AZ-01A to pump pit AZ-02A

- pump pit AN-01A to pump pit AP-04D

- new AZ valve pit to 241-AP valve pit

- pump pit AY-02A to new AZ valve pit

- pump pit AY-01A to pump pit AY-02A

- new $A Z$ valve pit to $P C$ interface point

- connecting LIQW-702 to SN-220

\subsubsection{Vent/Heater Control Panel.}

Selected MCCs, heater controllers, and HVAC control panels will be replaced or upgraded in AY/AZ Tank Farms.

\subsubsection{Backup Power System.}

A receptacle that will allow connection of a backup diesel generator (provided by others) shall be provided for the primary ventilation systems for the 241-AN, AP, and AW Tank Farms.

\subsubsection{Auxiliary Electrical Power.}

The system shall supply 480 Vac to $240 / 120$ Vac mini-power stations in the DST Farms and for 244-S DCRT.

\subsubsection{Spare Circuit Breakers.}

The electrical distribution system shall provide spare main circuit breakers for the AN and AW Tank Farms.

\subsubsection{Cathodic Protection System.}

The system shall provide cathodic protection (as required) for all new piping in the DST Tank Farms and in DCRT 244-S.

\subsubsection{DCRT Annulus Leak Detection.}

The leak detection system shall monitor the DCRT 244-S annulus for tank waste liquid leaks. The current method of leak detection using specific gravity measurements (SpG-WF method) within the DCRT annulus sump shall be replaced with better technology.

\subsubsection{Valve Position Indicators.}

The valve position indicators shall be installed on the waste transfer valves in Valve Pits $A N-A$, AN-B, 241-AP, AW-A, AW-B; Pump Pits AN-01A, AN-04A, AY-02A, AZ-01A, and AZ-02A.

\subsubsection{Freeze Protection.}

The electrical distribution system shall provide electrical power for freeze protection of the seal pots and drainage systems installed by Project W-314.

\subsubsection{New AZ Valve Pit.}

A new $A Z$ valve pit will be provided to facilitate transfers in support of the Waste Feed Delivery Program. 
HNF-SD-W314-DRD-001, Rev. 2

\section{SYSTEM QUALIFICATION PROVISIONS}

\subsection{General.}

Inspections as defined in 4.2 shall be conducted during the design and development of each system to provide assurance of compliance with the requirements of this DRD.

\subsubsection{Responsibility for Inspections.}

The design contractor shall be responsible for the performance of all inspections for each system developed in accordance with this DRD. Inspections shall be conducted at the contractor facilities or the facilities of his choice with the approval of the procuring authority. The procuring authority reserves the right to witness or perform the specified inspections.

\subsubsection{Special Tests and Examinations.}

This paragraph is not applicable to this document.

\subsection{Quality Conformance Inspections.}

Qualification shall be performed on System hardware representative of the approved production design. Qualification of the System to assure compliance with the requirements of section 3 shall be by examination, demonstration, test, and/or analysis, as defined herein. Test program data may be used to assure compliance with requirements.

a. Examination is an element of inspection consisting of investigation, without the use of special laboratory appliances or procedures to determine compliance with requirements.

b. Demonstration is an element of inspection that is limited to readily observable functional operation to determine compliance with requirements. This element of inspection does not require the use of special equipment or sophisticated instrumentation.

c. Test is an element of inspection that employs technical means including (but not limited to) the evaluation of functional characteristics by use of special equipment or instrumentation, simulation techniques, and the application of established principles and procedures to determine compliance with requirements. The analysis of data derived from test is an integral part of this inspection.

d. Analysis is an element of inspection, taking the form of the processing of accumulated results and conclusions, intended to provide proof that verification of a requirement(s) has been accomplished. The analytical results may be comprised of a compilation of interpretation of existing information or derived from lower level examinations, tests, demonstrations, or analyses.

The environmental capability of equipment shall be demonstrated by appropriate testing, analysis, and operating experience, or other methods that can be supported by auditable documentation, or a combination of these methods. 
HNF-SD-W314-DRD-001, Rev. 2

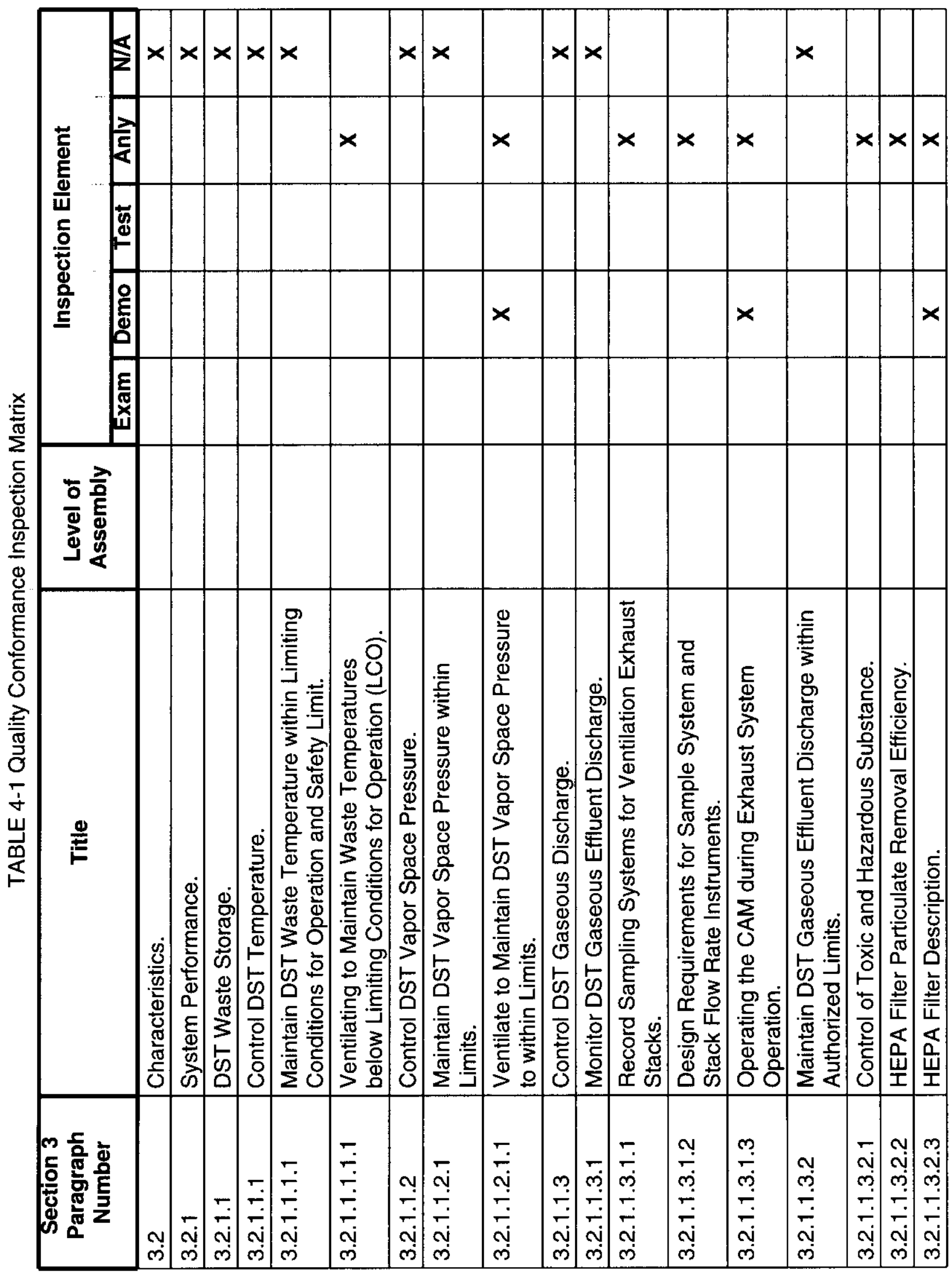


HNF-SD-W314-DRD-001, Rev. 2

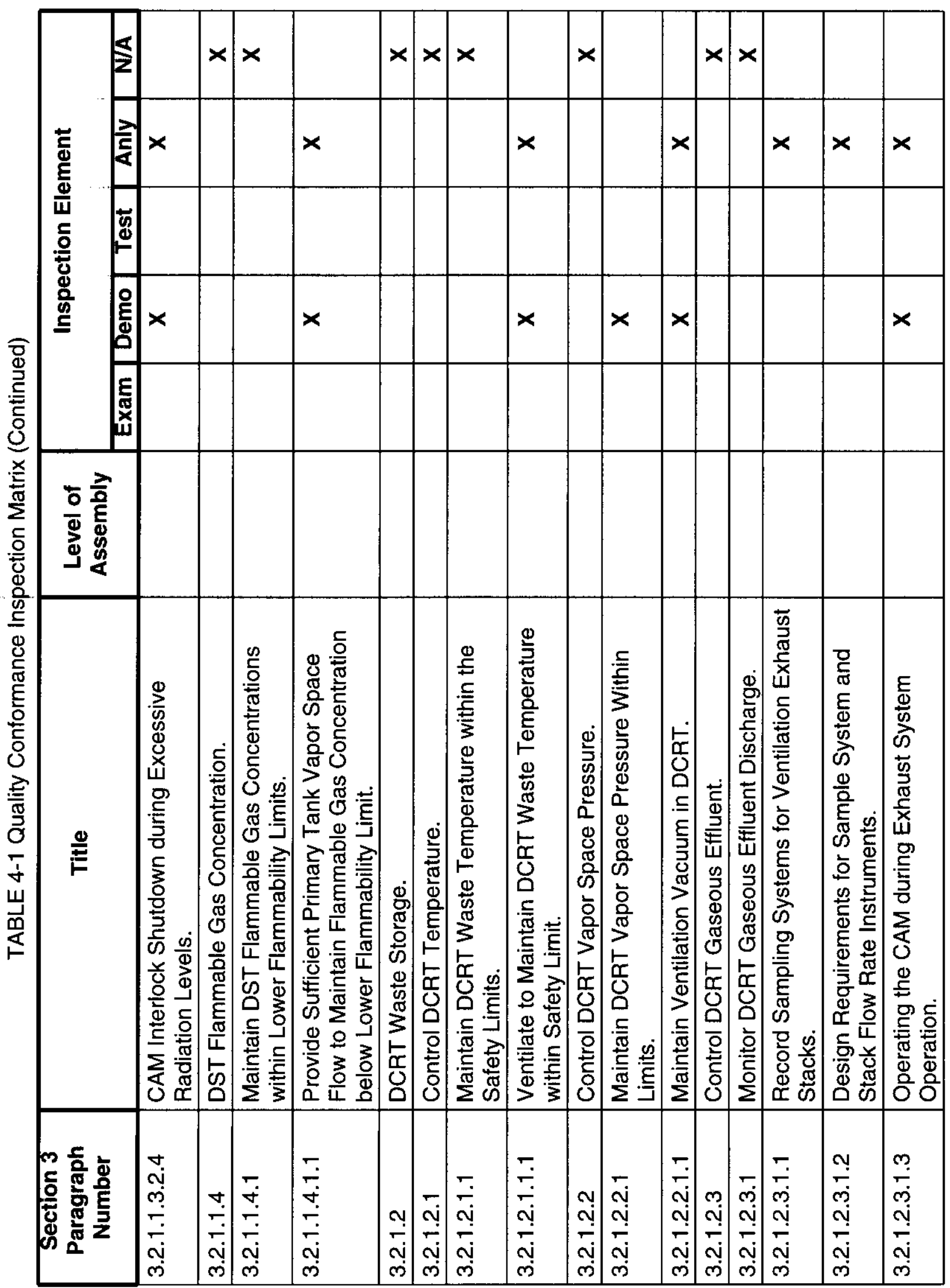


HNF-SD-W314-DRD-001, Rev. 2

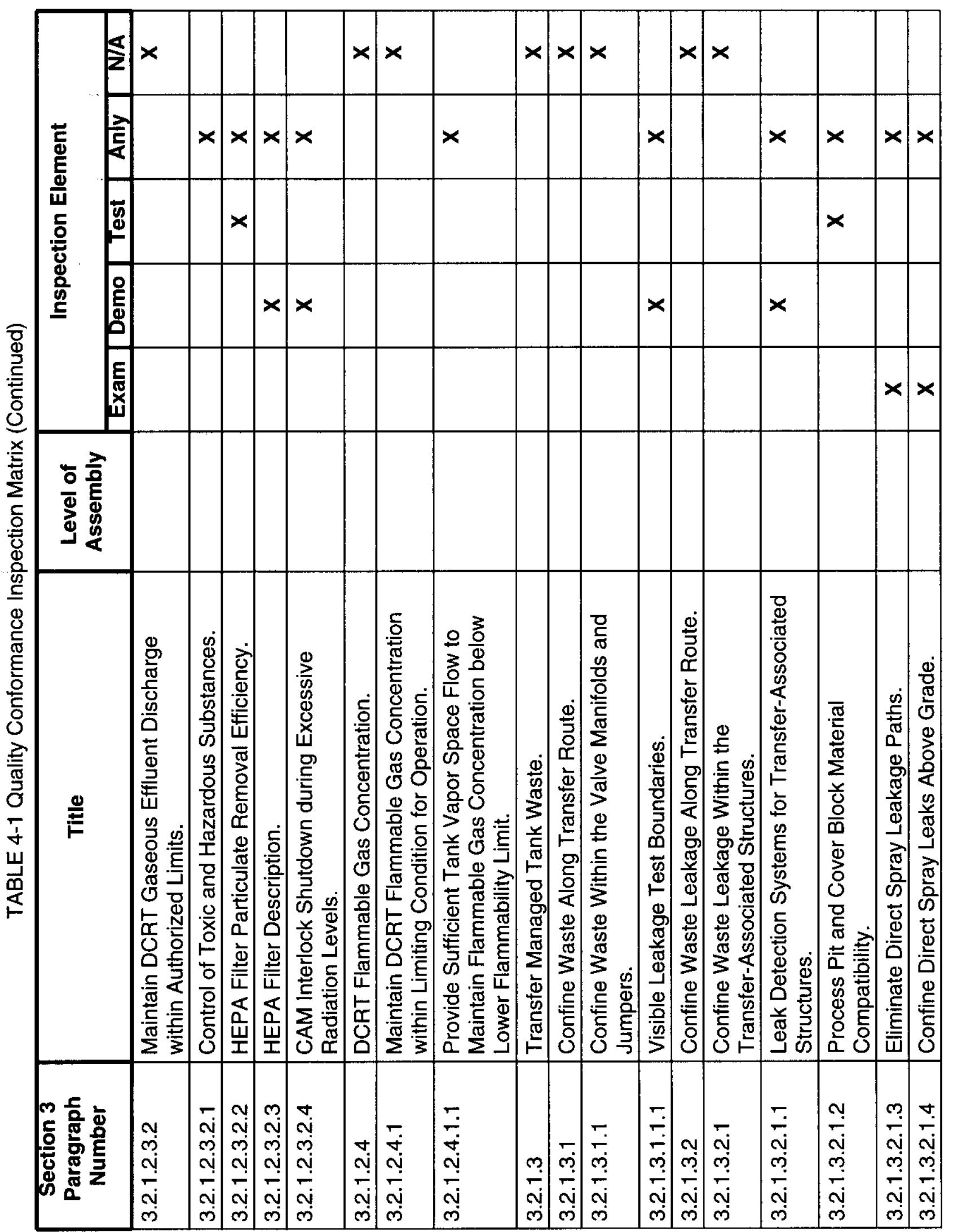


HNF-SD-W314-DRD-001, Rev. 2

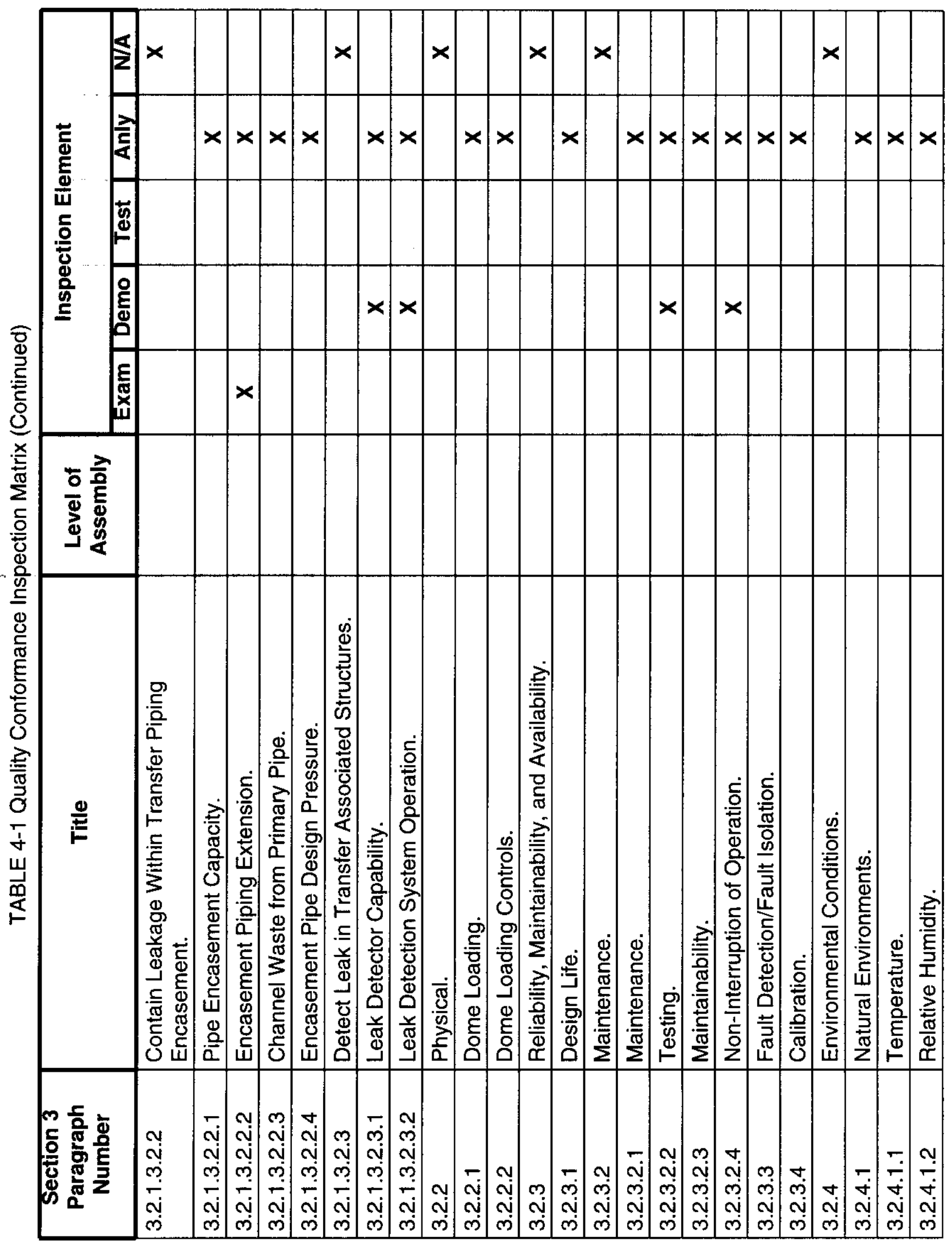


HNF-SD-W314-DRD-001, Rev. 2

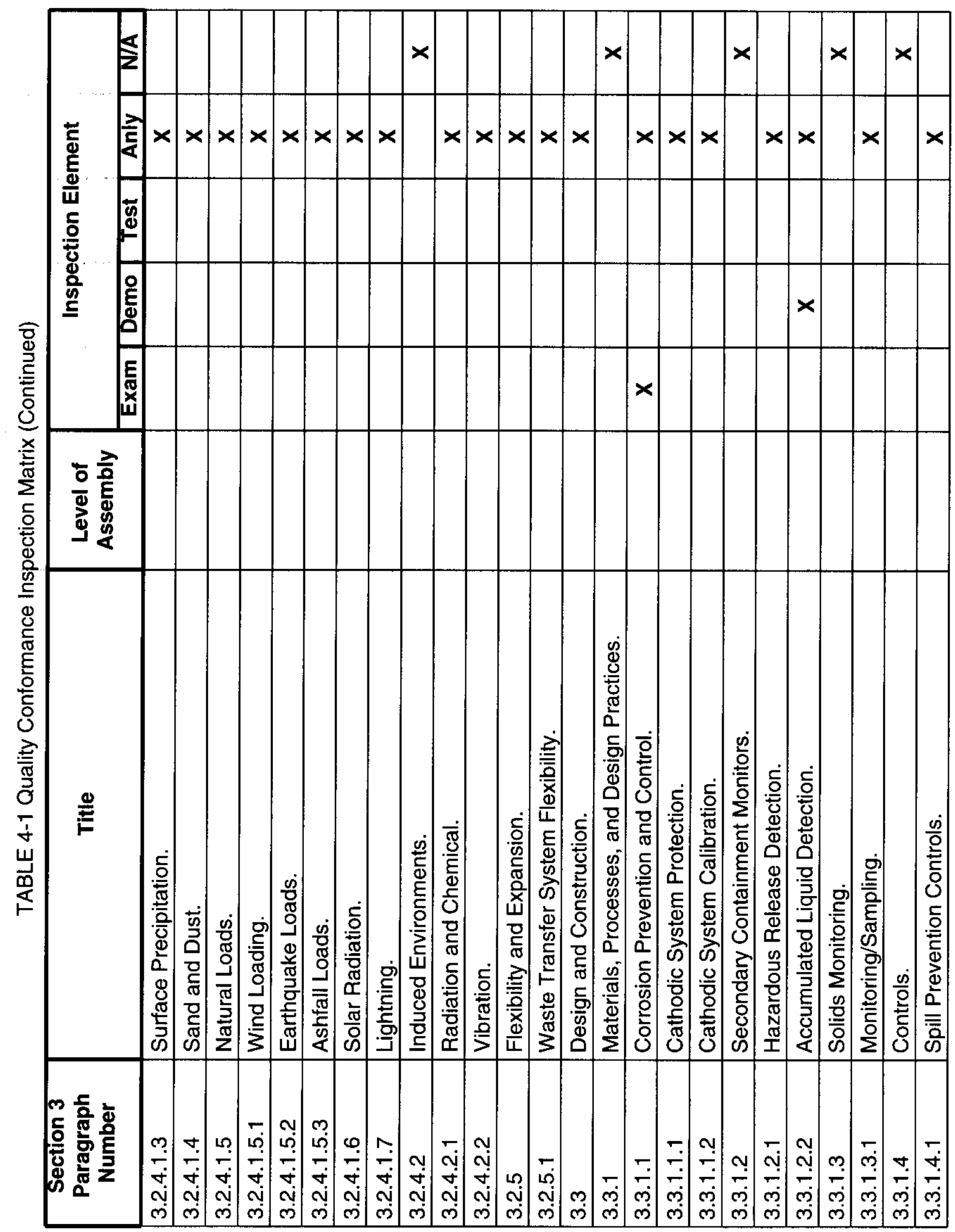


HNF-SD-W314-DRD-001, Rev. 2

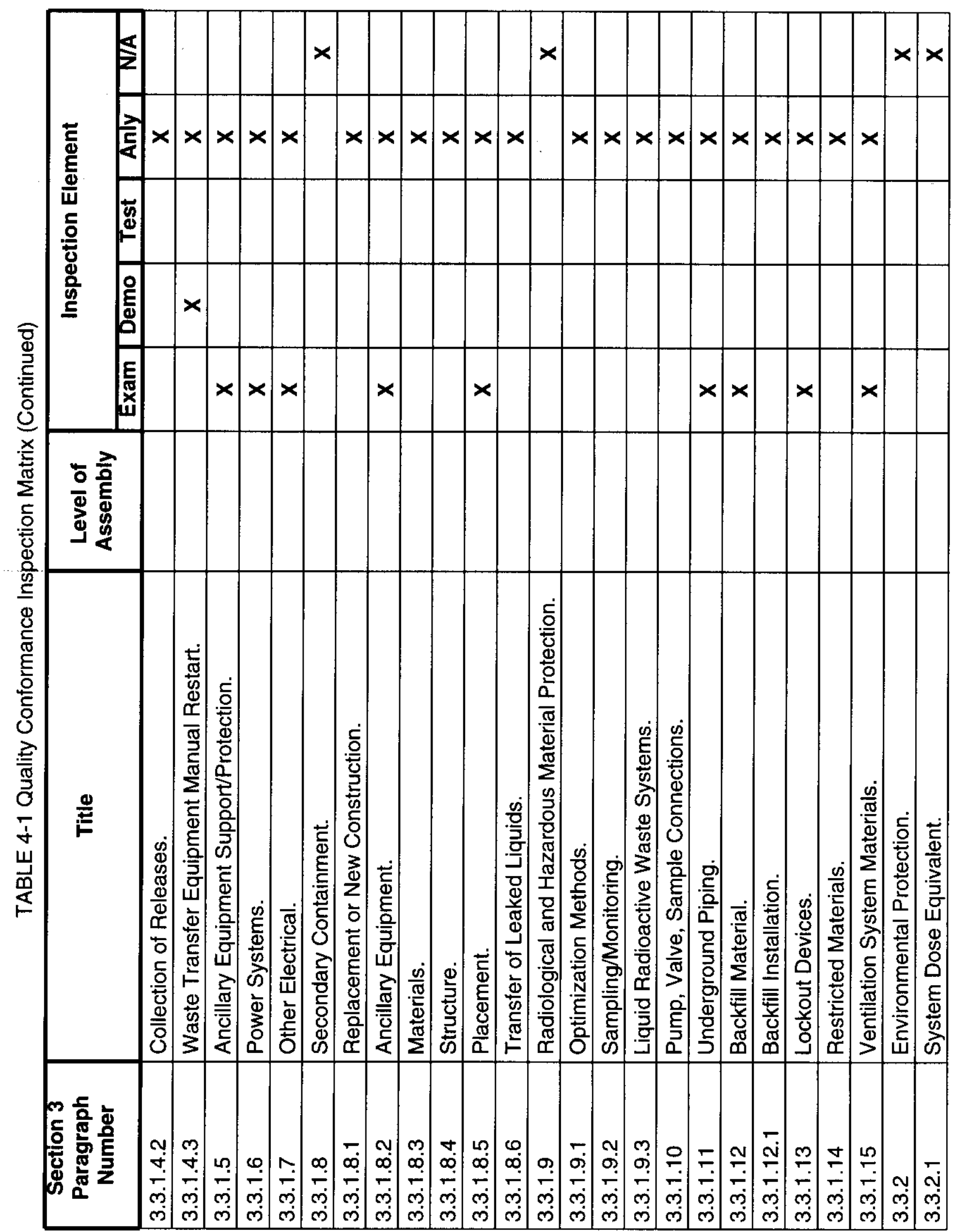


HNF-SD-W314-DRD-001, Rev. 2

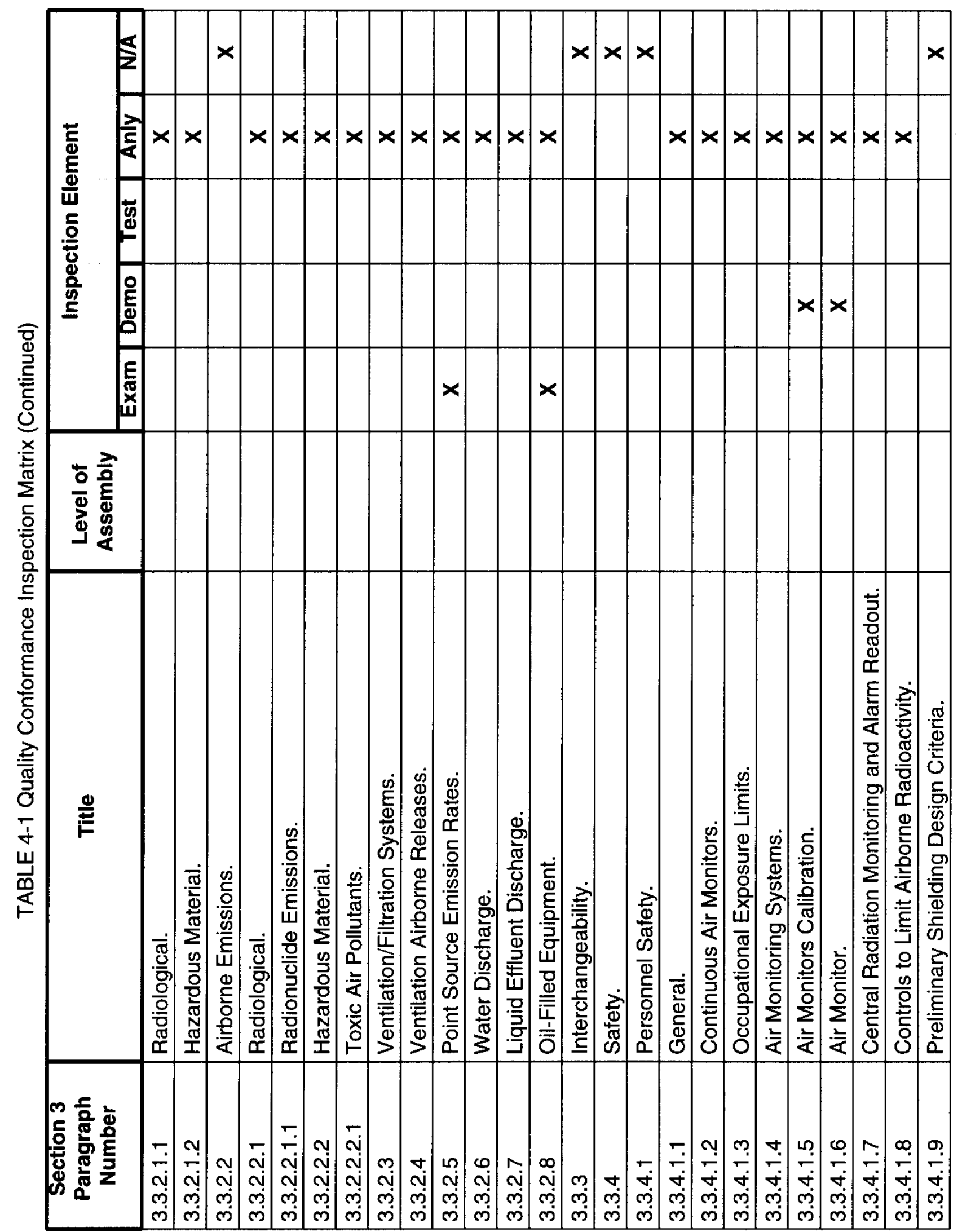


HNF-SD-W314-DRD-001, Rev. 2

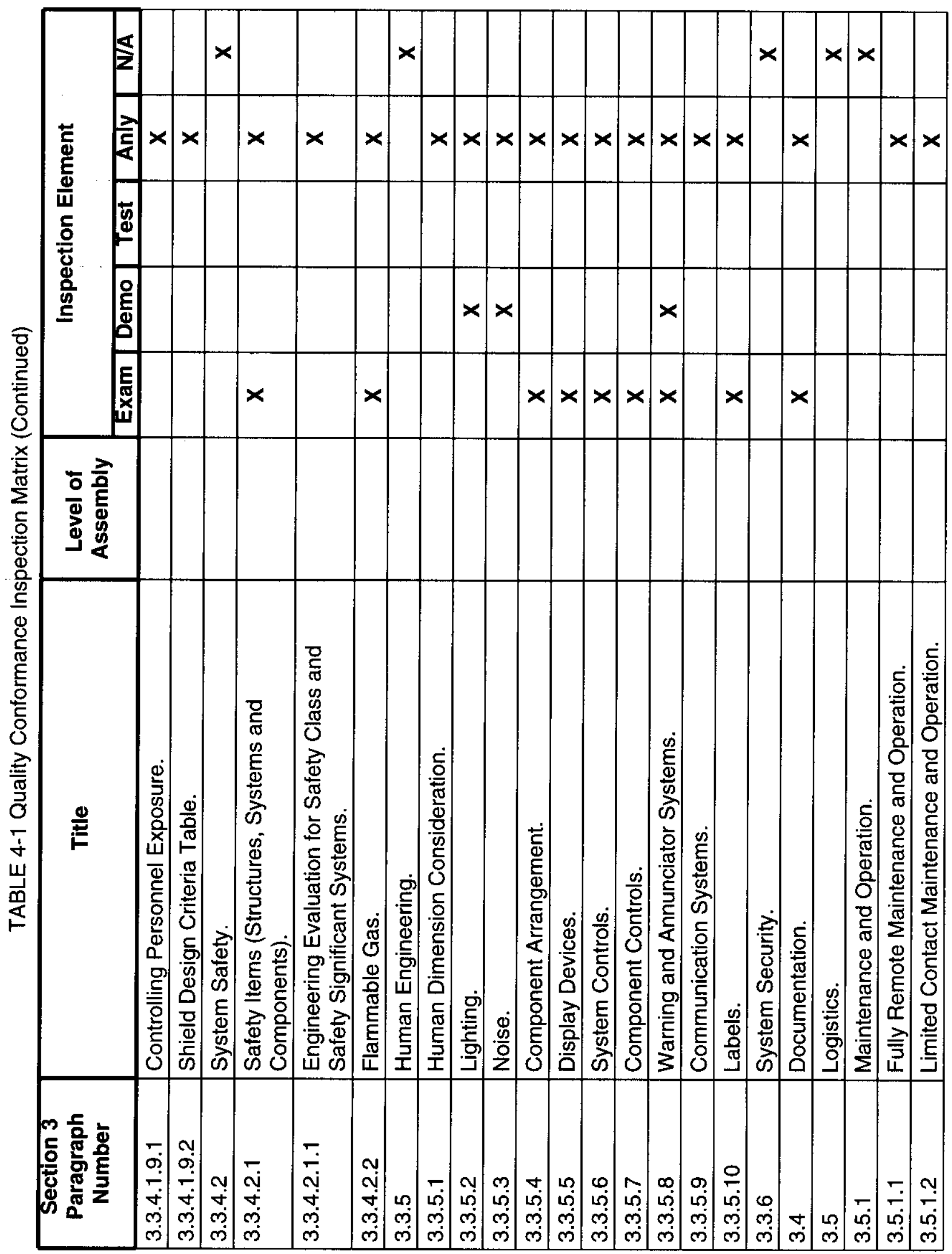


HNF-SD-W314-DRD-001, Rev. 2

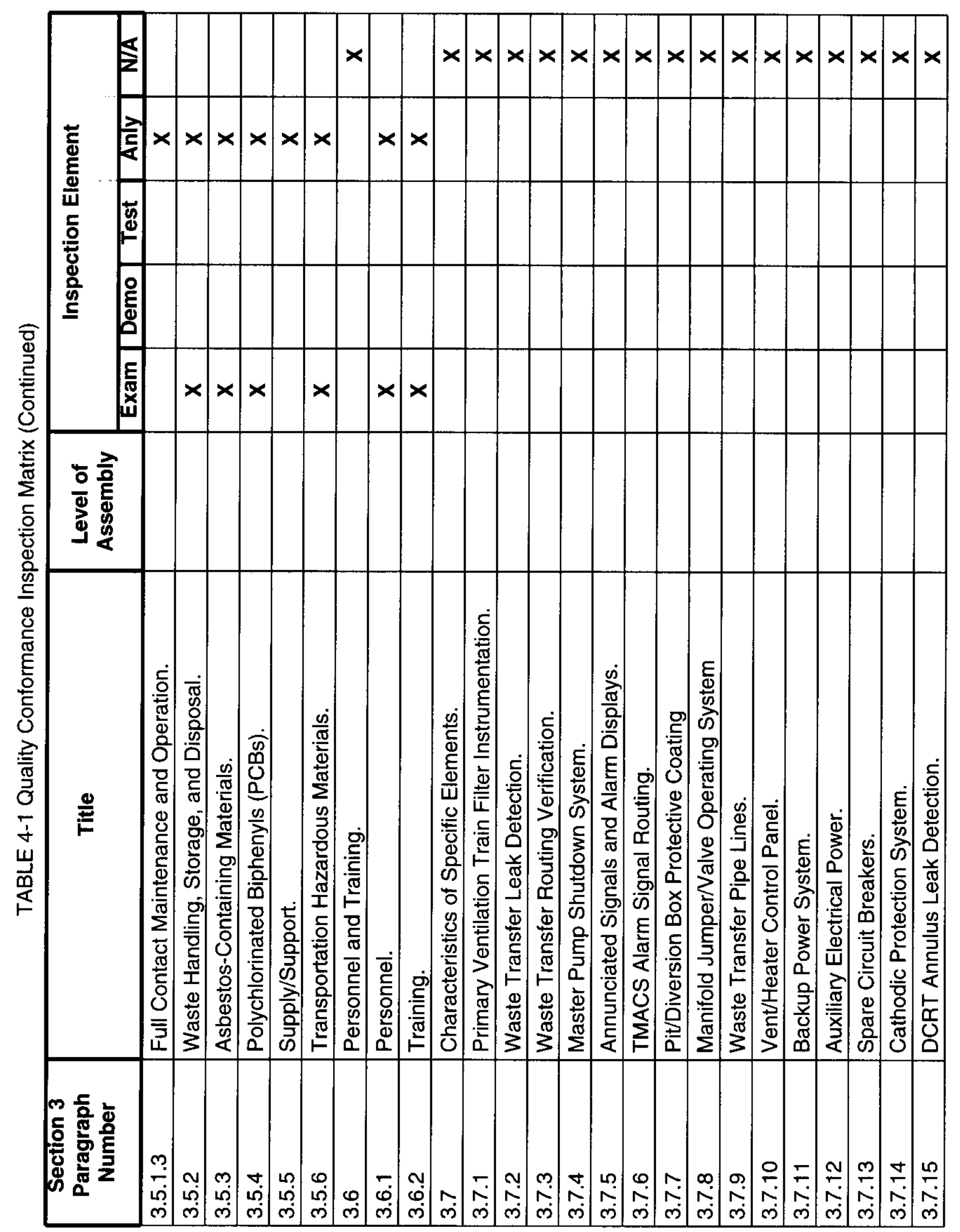


HNF-SD-W314-DRD-001, Rev. 2

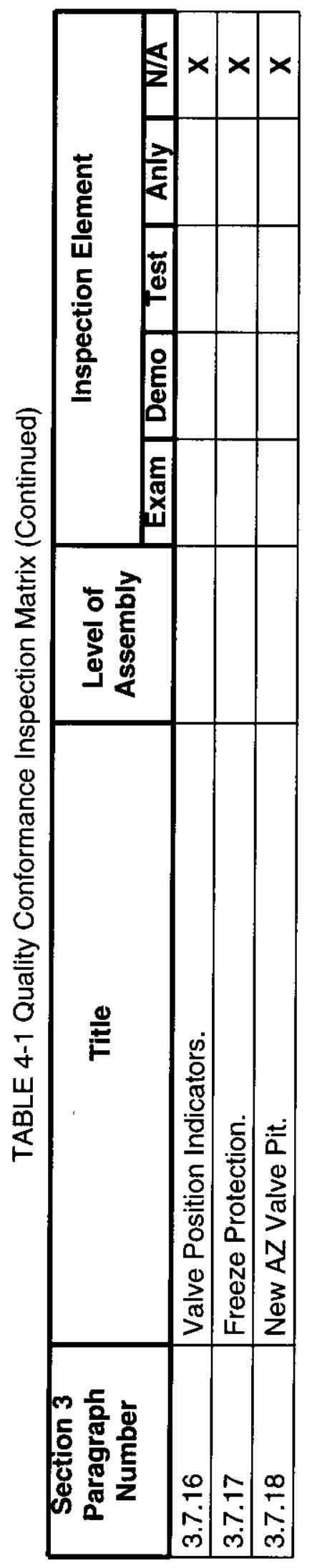




\section{NOTES}

\subsection{Definitions.}

\subsubsection{Abnormal.}

Deviation outside the normal (for instance, physical conditions outside of the LCO) which may lead to uncontrollable events.

\subsubsection{Characterize Waste.}

Provide physical, chemical, and radiological characterization information to support process control, safety issue resolution, treatment/storage/disposal decisions, or other RPP needs (e.g., characterization during and after retrieval operations). Involves acquisition and transfer of samples to a laboratory and in situ measurements.

\subsubsection{Concentrate Waste.}

Remove excess water from liquid DST waste to reduce volume of waste feed for treatment and to free up storage capacity in existing tanks.

\subsubsection{Design Life.}

Design life of a system is the length of time that a system can be employed to perform its specified functions to their specified levels of performance with the application of prescribed maintenance procedures, and without major overhaul or refurbishment. Maintenance procedures may allow for repair or replacement of selected components. Design life starts at the point of acceptance of the system by the operator for use. The service life of a system can be extended beyond design life with major overhaul or refurbishment of selected components.

\subsubsection{Double-Shell Tanks.}

The Double-Shell Tanks (DSTs) are underground tanks which consist of a carbon steel primary tank, an annular space, and a secondary steel tank encased in reinforced concrete. These tanks which are used for storage of radioactive liquid chemical waste are located within the 200 East and 200 West Area tank farms (241-AN, AP, AW, AY, AZ, and SY tank farms).

\subsubsection{Emergency Mission Records.}

Departmental emergency mission records, determined by the relationship of the record to the assigned essential emergency function.

\subsubsection{General Management Record.}

Statements of emergency mission; plans and programs for carrying out that mission; delegations of authority; successions of command; regulations or announcements drafted for emergency purposes; outlines of action programs; listings of emergency operating and records storage locations; listings of Department personnel, property, and activities sufficient to provide a basis for damage assessments; descriptions of essential emergency functions; and copies of basic legislation, regulations, and procedures.

\subsubsection{Industrial Records.}

Engineering drawings, explanations of complex industrial processes, and lists of supplies and suppliers for items and materials not readily available. 


\subsubsection{Retrieve Waste.}

Remove tank waste from SSTs, DSTs, and miscellaneous tanks for transfer to other facilities. Wastes to be removed from the tanks shall include liquids, saltcake, sludge, slurries, and solids (e.g., failed equipment, concrete, rocks, lead bricks, samarium balls, and cobalt slugs). Solids shall be removed only to the extent necessary to prevent interference with the retrieval of other wastes or as required to allow completion of closure activities.

\subsubsection{Safety Class Structures.}

The correlation among safety class designations in DOE 6430.1A, the performance category terms in DOE O 420.1, and safety class terminology in this document is provided by HNF-PRO-097, Engineering Design and Evaluation and is shown in table 5.1 below. 
HNF-SD-W314-DRD-001, Rev. 2

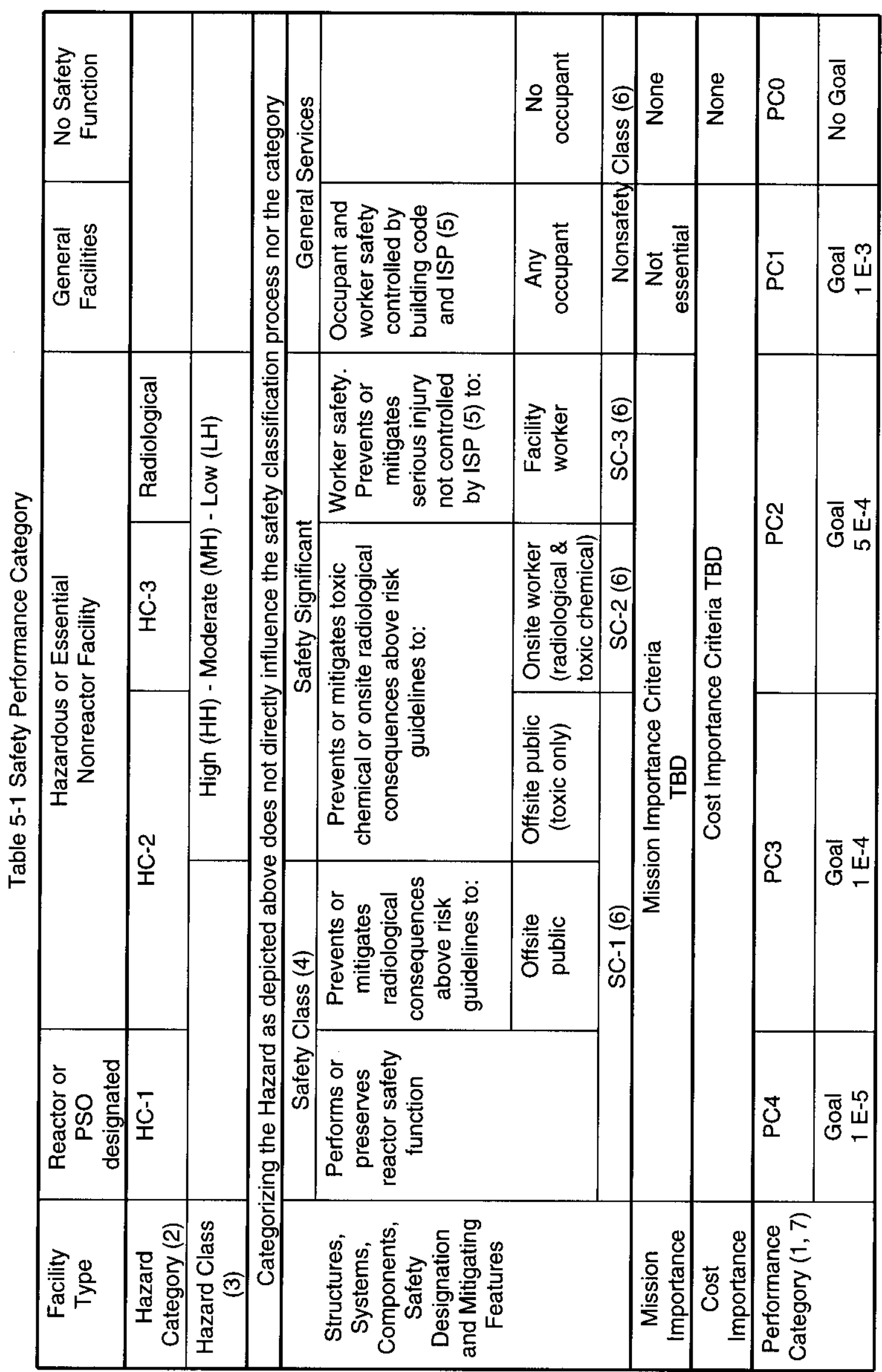




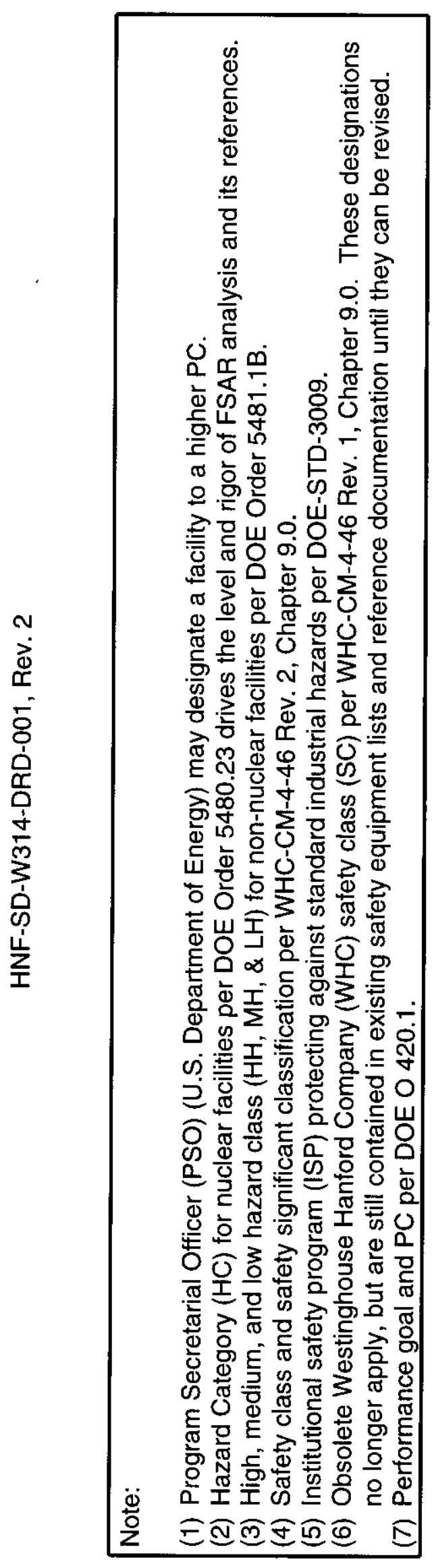




\subsubsection{Safety Classification.}

Identification of Safety Class and Safety Significant structures, systems, and components (SSCs) will be determined in accordance with HNF-PRO-704, Hazard and Accident Analysis Process.

\subsubsection{Secondary Containment.}

The secondary containment systems shall prevent any migration of wastes or accumulated liquid out of the system to the soil, groundwater, or surface water at any time during the use of the tank system.

\subsubsection{Single-Shell Tanks.}

The Single-Shell Tanks (SSTs) are underground, reinforced concrete, carbon steel lined tanks used for storage of radioactive liquid chemical waste. These tanks are located within the 200 East and 200 West Area tank farms (241-A, AX, B, BX, BY, C, S, SX, T, TX, TY, and U tank farms).

\subsubsection{Store Waste.}

Contain and monitor SST waste and waste in miscellaneous tanks. Receive, contain, and monitor DST waste and in-process waste.

\subsubsection{System.}

An integrated composite of people, products, and processes that provide a capability to satisfy a stated need or objective. Note the following example system:

I\&C System: The hardware, software, personnel and processes necessary to monitor and control the physical parameters and the behavior of a given plant equipment or process. Monitoring and control may be manually or automatically performed.

\subsubsection{Tank Intrusion}

Used in this document to describe unauthorized additions to the tanks.

\subsubsection{Transfer Waste.}

Move retrieved liquid, and slurry tank waste from SSTs, DSTs and miscellaneous tanks to treatment facilities or other storage locations. Move new tank waste from facilities outside of RPP to treatment or to storage. This function does not encompass waste sample transfers, transfers within treatment facilities, or transfers to and from the evaporator, but does include the transfers of in-process waste and transfers of secondary waste.

\subsubsection{Project/Plan Definitions.}

\subsubsection{W-211 Initial Tank Retrieval System.}

$W-211$ is tasked with the full retrieval mission of the 10 high priority double shell tanks. The effort will involve the installation of mixer pumps to mobilize the waste within the tanks, installation of waste transfer pumps, and associated piping and valve pits which will convey the waste to the tank farm boundary. W-211 will be installing instrument and control buildings to provide local monitoring and control of the system. It will also connect the instrumentation and 
controls to the existing control facilities, 242-S and 242-A. W-211 will be designed and constructed in three phases (see Section 2.0 for schedule dates). The first phase consists of tanks SY-101, SY-103 and AW-101. The second phase consists of tanks AN-103, -104, -105 , and -106 . The third and last phase consists of tanks AZ-102, AY-102, and AP-101.

\subsubsection{W-519, Privatization Infrastructure Phase 1 Support System.}

W-519 will provide key utilities and necessary infrastructure to support the privatization contractors. This includes electricity, raw water, sanitary water, site development and roads, and liquid effluent lines. Location of the privatization facilities is in the southeast corner of $200 \mathrm{E}$.

\subsubsection{Project W-521, Waste Feed Delivery.}

W-521 will upgrade or provide the additional systems and equipment, not provided by other projects, that are necessary to complete Phase 1 WFD for tanks 241-AN-101, 241-AN-102, 241-AN-106, 241-AN-107, 241-AW-101, 241-AW-103, 241-SY-101, 241-AY-101, and 241-AZ-101.

\subsubsection{Project W-522, DST Retrieval.}

W-522 will provide retrieval systems, including mixer pumps and transfer pumps in AP, AW, and SY Tank Farms, to allow the waste from two watchlist double shell tanks to be retrieved for processing by the private waste processing contractor. Ventilation and effluent monitoring upgrades will be provided to meet applicable regulatory requirements. Instrumentation capable of monitoring solids settling and identifying the solid/liquid interface in the tank will be installed.

\subsection{Abbreviations and Acronyms.}

The acronyms and abbreviations listed below are used in this specification.

$\begin{array}{ll}\text { ALARA } & \text { As Low As Reasonably Achievable } \\ \text { AR } & \text { Administrative Record } \\ \text { ASME } & \text { American Society of Mechanical Engineers } \\ \text { ATP } & \text { Acceptance Test Procedure } \\ \text { AWF } & \text { Aging Waste Facility } \\ \text { BIO } & \text { Basis for Interim Operations } \\ \text { C } & \text { Celsius/Centigrade } \\ \text { CAM } & \text { Continuous Air Monitor } \\ \text { cfh } & \text { cubic feet pre hour } \\ \text { CFR } & \text { Code of Federal Regulations } \\ \text { cm } & \text { centimeter } \\ \text { COB } & \text { Clean Out Box } \\ \text { DAC } & \text { Derived Air Concentration } \\ \text { DBA } & \text { Design Basis Accident } \\ \text { DCRT } & \text { Double Contained Receiver Tank } \\ \text { dia } & \text { diameter } \\ \text { DOE } & \text { Department of Energy } \\ \text { DRD } & \text { Design Requirements Document } \\ \text { DST } & \text { Double Shell Tank } \\ \text { EDE } & \text { Effective Dose Equivalent } \\ \text { EPA } & \text { Environmental Protection Agency } \\ \text { F } & \text { Fahrenheit } \\ \text { ft } & \text { feet } \\ \text { gm } & \text { gram }\end{array}$


HNF-SD-W314-DRD-001, Rev. 2

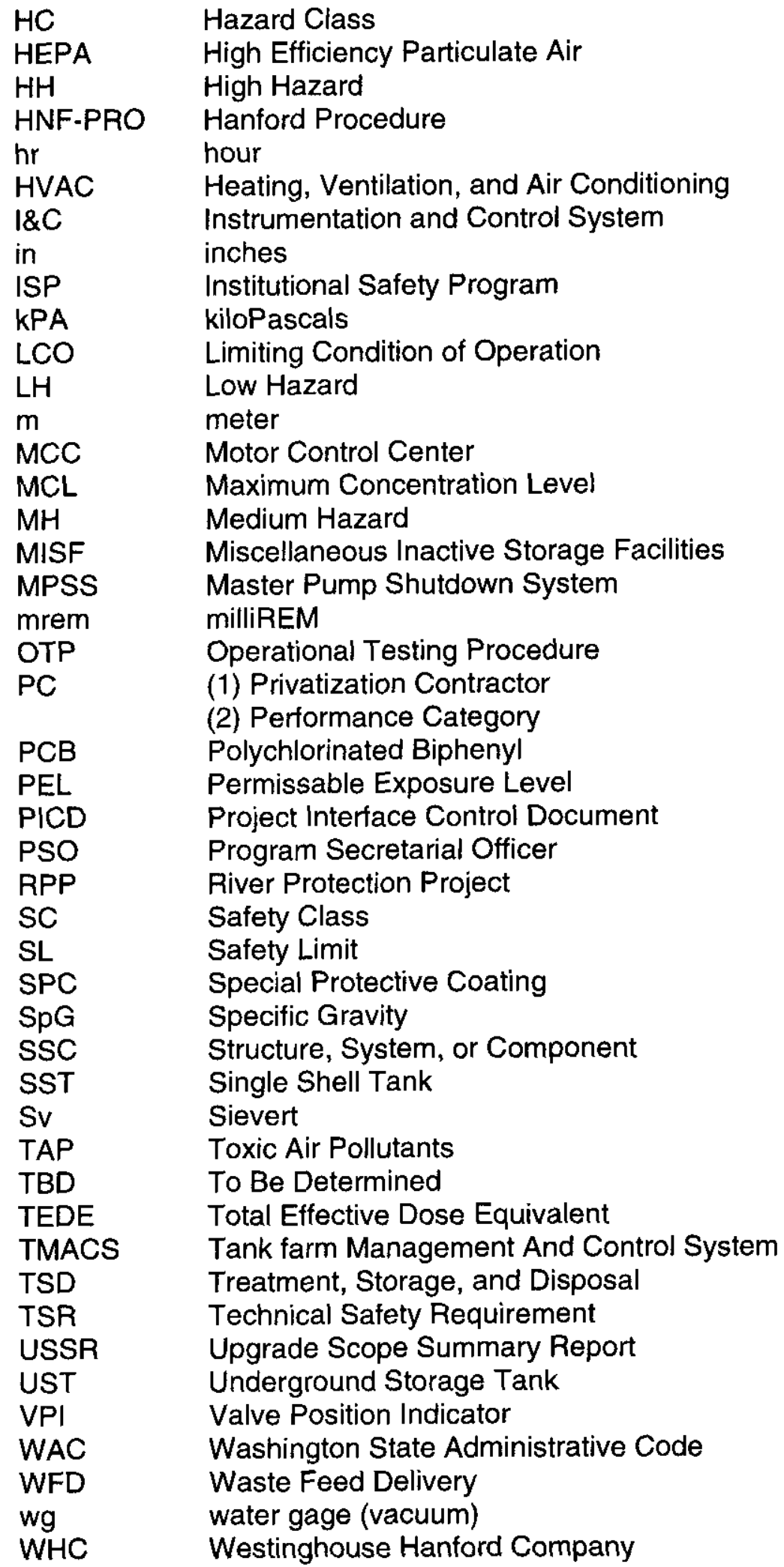


DISTRIBUTION SHEET

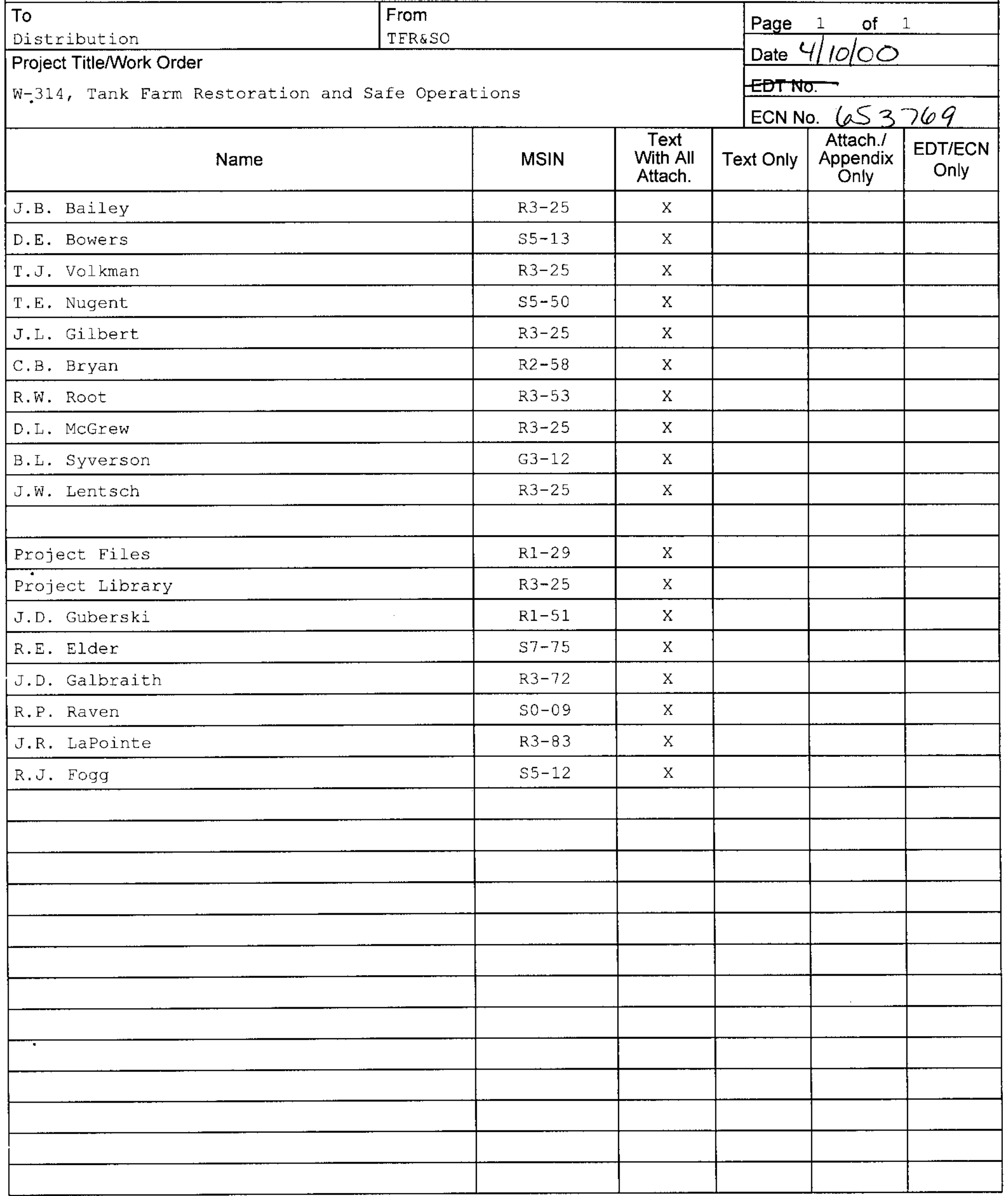

